\title{
Estados federativos, cortes supremas e dívidas estaduais: um estudo do efeito de decisões recentes do STF sobre a credibilidade das medidas de ajuste fiscal implementadas ao longo da década de 1990*
}

\author{
Federations, Supreme Courts and States'debts: \\ a study of the effect of recent Brazilian Supreme Court's rulings on the credibility of fiscal \\ adjustment measures implemented in the 1990s
}

Fernando Bertoletti Bastos ${ }^{* *}$

\begin{abstract}
REFERÊNCIA
BASTOS, Fernando Bertoletti. Estados federativos, cortes supremas e dívidas estaduais: um estudo do efeito de decisões recentes do STF sobre a credibilidade das medidas de ajuste fiscal implementadas ao longo da década de 1990. Revista da Faculdade de Direito da UFRGS, Porto Alegre, n. 44, p. 50-84, dez. 2020. DOI:

https://doi.org/10.22456/0104-6594.95288.
\end{abstract}

\section{RESUMO}

Alguns anos atrás, muitos supunham que, ainda que no passado a União tivesse socorrido Estados endividados mais de uma vez, após ter aprovado um marco legal mais rigoroso em matéria fiscal que proíbe, em regra, operações de crédito entre entes federativos, o Brasil havia finalmente controlado os problemas sistemáticos da indisciplina fiscal e do endividamento em nível estadual. Nos últimos anos, no entanto, observam-se indícios muito claros de que tais problemas voltaram a se manifestar no país. Nessas circunstâncias, alguns Estados acudiram ao Supremo Tribunal Federal na tentativa de não serem penalizados pelo inadimplemento dos contratos decorrentes dessas operações de resgate ou pelo descumprimento de disposições previstas na legislação fiscal, tendo obtido decisões favoráveis em alguns casos. Tais decisões foram criticadas por órgãos ligados ao Poder Executivo federal por terem, basicamente, flexibilizado os incentivos previstos tanto nos contratos como na legislação para que os Estados mantivessem um comportamento disciplinado em matéria fiscal. O presente estudo propõe-se a examinar, com base em um ramo da literatura sobre federalismo fiscal, que se ocupa das relações entre a credibilidade do compromisso da União de não socorrer Estados endividados, de um lado, e a disciplina fiscal de Estados, de outro, o efeito de algumas decisões do STF em tais questões sobre os desdobramentos da crise das dívidas estaduais no Brasil, pondo à prova tal crítica.

\section{PALAVRAS-CHAVE}

Federalismo Fiscal. Dívidas Estaduais. Resgates Federais. Cortes Supremas.

\footnotetext{
* Este artigo é uma versão revista, ampliada e atualizada do trabalho apresentado pelo autor na disciplina "Federalismo Comparado: Teorias e Explicações" do Programa de Pós-Graduação Stricto Sensu do Departamento de Ciência Política da FFLCH/USP. O autor agradece a Prof ${ }^{a}$ Marta Arretche, que ministrou a referida disciplina, pelos comentários e sugestões feitos quando da avaliação do trabalho, bem como aos pareceristas anônimos que analisaram a versão que foi posteriormente submetida a esta Revista, o que evidentemente não retira do autor a responsabilidade por eventuais equívocos e/ou inconsistências contidos neste artigo. Ressalte-se, por fim, que esta pesquisa foi desenvolvida e este artigo elaborado quando o autor era bolsista do CNPq, cujo apoio foi de grande importância para essa realização.

** Bacharel pela Faculdade de Direito da Universidade Federal do Paraná - UFPR (2009). Máster Universitario en Derecho Constitucional promovido pelo Centro de Estudios Políticos y Constitucionales, em aliança acadêmica com a Universidad Internacional Menéndez Pelayo (2013). Doutor em Direito do Estado pela Faculdade de Direito do Largo de São Francisco da Universidade de São Paulo - USP (2020). Bolsista de doutorado do CNPq à época da submissão do artigo.
} 


\begin{abstract}
Some years ago, many assumed that, despite the fact that in the past the Union had more than once bailed out indebted states, after having approved a more rigid fiscal legislation that forbids, as a general rule, credit operations among them, Brazil had finally contained the systematic problems of state-level fiscal indiscipline and indebtedness. In recent years, however, there are very clear indications that these problems are once again present in the country. In such scenario, some states have resorted to the Brazilian Supreme Court in an attempt to not be sanctioned for failing to comply with either bailout contracts obligations or fiscal legislation provisions, obtaining favorable rulings in some cases. These decisions were criticized by part of the Executive for, essentially, loosening the contractual as well as legal incentives that prompt the states to maintain a disciplined behavior in fiscal matters. This article aims to examine, based on a strand of literature on fiscal federalism that focuses on the relationship between the credibility of the Union's no-bailout commitment, on the one hand, and states' fiscal discipline, on the other, the effect of some of the Supreme Court's rulings concerning such issues on the developments of the states' debt crisis in Brazil, submitting that critique to test.
\end{abstract}

\title{
KEYWORDS
}

Fiscal Federalism. States’ Debts. Federal Bailouts. Supreme Courts.

\section{SUMÁRIO}

1. Introdução. 2. Referencial teórico: o "no-bailout credible commitment”. 3. União resgata Estados sucessivas vezes, mas se compromete a não mais os socorrer (1989-2001). 4. Estados desafiam o compromisso da União no Congresso Nacional e conseguem renegociar antigas dívidas (2013-2016). 5. Após um Estado obter uma liminar no STF, outros adotam a mesma estratégia e conseguem novas concessões da União (2016-2017). 6. Com alguns Estados em "situação calamitosa”, o STF concede novas liminares e é alvo de críticas (2016-2018).

7. Conclusão. Referências. Dados da publicação. 


\section{INTRODUÇÃO}

Como se verá ao longo do presente trabalho, há cerca de 10 anos, acreditava-se que, apesar de, no passado, a União ter socorrido Estados endividados sucessivas vezes (1989, 1993 e 1997), após a aprovação de importantes reformas ao longo da década de 1990, como o Programa de Reestruturação e de Ajuste Fiscal (PAF) em 1997 e a Lei de Responsabilidade Fiscal (LRF) em 2000 - a qual proíbe, em regra, a realização de novas operações de crédito entre entes federativos ou o refinanciamento das dívidas já existentes -, que compuseram a agenda de governo do ex-Presidente FHC (1995-2002), o Brasil havia, se não completamente superado, ao menos controlado os problemas sistemáticos da indisciplina fiscal e do endividamento em nível estadual. Nos últimos anos, porém, observam-se indícios muito claros de que tais problemas voltaram a se manifestar: em 2017, os quatro Estados mais ricos da Federação brasileira (SP, RJ, MG e RS), que são também os quatros Estados que mais devem à União, extrapolaram o limite de endividamento estabelecido pelo Senado Federal $^{1}$; nesse mesmo ano, a maior parte dos Estados brasileiros (14/26) descumpriu o limite de despesas com pessoal previsto na $\mathrm{LRF}^{2}$; e, desde meados de 2016, pelo menos um em cada quatro Estados brasileiros (7/26) decretou, em algum momento, o chamado "estado de calamidade financeira"3.

Mas como explicar esses resultados se o país conta hoje com um marco legal mais rigoroso em matéria fiscal? O debate costuma concentrar-se em basicamente dois aspectos: de um lado, nos defeitos ou imperfeições presentes na legislação que teriam permitido que suas disposições fossem, em certos casos, contornadas; e, de outro, no fato de que essa seria rotineiramente descumprida, o que teria contado com uma certa tolerância por parte de órgãos encarregados de sua fiscalização. Embora tal distinção não seja trivial, o fato é que, tanto em um caso como no outro, o que está em questão, no caso brasileiro, é a própria credibilidade das medidas de ajuste fiscal que foram implementadas ao longo da década de 1990. Por esse motivo, o presente estudo propõe-se a analisar o "reaparecimento" dos

\footnotetext{
${ }^{1}$ RJ, RS, SP e MG, em ordem decrescente. BRASIL. Boletim de finanças dos entes subnacionais: 2018. Brasília: Ministério da Fazenda. Secretaria do Tesouro Nacional, 13 nov. 2018, p. 31.

${ }^{2}$ MG, MS, RN, RJ, RS, MT, SE, AC, PB, RR, PR, BA, SC e AL, em ordem decrescente. BRASIL. Boletim de finanças dos entes subnacionais: 2018, p. 24.

${ }^{3}$ Primeiro, o RJ por meio do Decreto n ${ }^{\circ} 45.692$, em junho de 2016; na sequência, RS e MG por meio dos Decretos $n^{\circ}$ 53.303 e 47.101, em novembro e dezembro do mesmo ano, respectivamente; mais recentemente, RR por meio do Decreto $n^{\circ}$ 26.404-E, em dezembro de 2018; e RN, MT e GO por meio dos Decretos nº 28.689, 07 e 9.392, em janeiro de 2019, também respectivamente.
} 
problemas da indisciplina fiscal e do endividamento estaduais no Brasil, à luz de um ramo da literatura sobre federalismo fiscal que relaciona o comportamento fiscal dos Estados à credibilidade do compromisso da União de não os resgatar (no-bailout credible commitment). Os autores desse referencial teórico partem da suposição de que aqueles não promoverão ajustes, cortando despesas ou elevando receitas, caso antecipem que serão por essa socorridos caso (haja risco de que) venham a quebrar.

Ressalte-se que aqueles resultados foram precedidos ou ocorreram paralelamente a alguns eventos relevantes: o processo de renegociação das condições da última operação de resgate que havia sido realizada em 1997, que ocasionou em 2015 a alteração do índice de correção monetária adotado e a redução dos juros previstos nos respectivos contratos; a controvérsia judicial em torno do método de cálculo dos novos juros das dívidas estaduais (se por juros simples ou compostos), que culminou em 2016 no alongamento dessas dívidas por mais 20 anos; e a criação em 2017 de um regime especial, abrindo exceções à LRF, a fim de evitar a quebra de Estados "superendividados" (regime ao qual um Estado já aderiu e outros já manifestaram a intenção de também aderir). Em todas essas ocasiões, verifica-se que a União fez - ou melhor, teve que fazer - concessões a Estados, algumas das quais, ao flexibilizarem medidas de ajuste fiscal que eram justamente a contrapartida daqueles nas operações de resgate, acabaram por reverter conquistas importantes que haviam sido por essa alcançadas ao longo da década de 1990.

É preciso observar que o Supremo Tribunal Federal (STF) se envolveu - ou melhor, foi envolvido -, de uma maneira ou de outra, em praticamente todos esses eventos. Estados endividados e em dificuldades financeiras acudiram à Corte para que não fossem penalizados pelo inadimplemento dos contratos de refinanciamento que celebraram com a União ou pelo descumprimento das medidas de ajuste fiscal que lhes foram impostas como contrapartida às operações de resgate. Considerando que muitos desses Estados obtiveram liminares no STF, algumas decisões da Corte passaram a ser criticadas por órgãos e agentes ligados ao Poder Executivo federal, em especial a Secretaria do Tesouro Nacional (STN), por flexibilizarem disposições que visam a assegurar o cumprimento desses contratos e das medidas de ajuste fiscal $^{4}$ - o que, pondo nos termos do referencial teórico, pode afetar a credibilidade do

\footnotetext{
${ }^{4}$ Para uma visão das diferentes críticas que foram por esses dirigidas a decisões recentes do STF nessas questões, vide: BRASIL. Exposição da União à insolvência dos entes subnacionais. Texto para discussão. Tesouro Nacional, nov. 2018, p. 79; MARTINS, Arícia. Judiciário precisa saber das consequências de decisões, diz
} 
compromisso da União de não socorrer Estados endividados. No presente estudo, pretende-se avaliar tais críticas e fazer, assim, uma singela contribuição à literatura, analisando, com base no caso brasileiro, os possíveis efeitos da atuação das chamadas Cortes Supremas em Estados federativos sobre o comportamento fiscal em nível estadual.

Além dessa breve introdução, o presente trabalho ${ }^{5}$ encontra-se dividido em cinco partes: a primeira tem por objetivo situar esse referencial teórico no debate acadêmico e descrever o mecanismo institucional identificado por seus autores para explicar o fenômeno; na segunda, pretende-se expor como surgiram as dívidas estaduais no Brasil e realçar as principais características das operações de resgate e do novo marco legal em matéria fiscal; na terceira, procura-se demostrar em que condições Estados "desafiaram" esse novo marco legal no Congresso Nacional e lograram rediscutir as condições da última operação de resgate; nas duas últimas partes, almeja-se analisar o efeito que algumas decisões recentes do STF tiveram sobre os desdobramentos da crise das dívidas estaduais no Brasil, a fim de submeter à prova algumas críticas que foram feitas a sua atuação. Para concluir, procura-se contrastar tais desdobramentos com o que seria esperado com base nesse referencial teórico, propondo novas reflexões a partir do caso brasileiro.

\section{REFERENCIAL TEÓRICO: O “NO-BAILOUT CREDIBLE COMMITMENT"}

Resgates de dívidas são um mecanismo para que Estados transfiram seu déficit fiscal ao governo federal. Se aqueles souberem que esse os socorrerá recorrentemente, os governos estaduais excederão seus gastos consistentemente.

(Afonso S. BEVILAQUA) ${ }^{6}$

Como resgates são benéficos a seus destinatários, mas onerosos aos contribuintes como um todo, o governo central pretenderá anunciar com firmeza ex ante que está determinado - que nunca optará por resgastes. Por uma série de motivos,

\footnotetext{
Mansueto. Valor Econômico, Brasília, 22 set. 2018; CARNEIRO, Mariana; WIZIACK, Julio. Decisão do STF abre brecha para que estados adiem pagamento à União. Folha de S. Paulo, $1^{\circ}$ out. 2018.

${ }^{5}$ Ressalte-se que, além das fontes bibliográficas, legislativas e jurisprudenciais, as referências feitas ao longo do presente trabalho e materiais oriundos da imprensa justificam-se pela atualidade do tema, na medida em que ainda há relativamente poucos estudos sobre seus desdobramentos mais recentes, bem como pelo registro que essa faz do debate público em torno dessas questões e das manifestações, interpretações, preferências e estratégias dos atores envolvidos.

${ }^{6}$ Tradução livre para: "Debt bailouts are a mechanism for states to transfer their fiscal deficits to the federal government. If they know that the federal government will recurrently bail them out, state governments will consistently overspend." BEVILAQUA, Afonso S. State-government bailouts in Brazil. Texto para discussão $\mathrm{n}^{\circ}$ 421. Departamento de Economia da PUC-Rio. Versão revisada. Mar. 2000, p. 34.
} 
entretanto, esse compromisso pode não parecer crível ex post, quando falências virem à tona ou escolas estiverem prestar a fechar.

(Jonathan A. RODDEN $)^{7}$

Passa-se, então, à exposição de um ramo da literatura sobre federalismo fiscal que se acredita ter potencial para explicar os desdobramentos mais recentes da crise das dívidas estaduais no Brasil. Os autores desses estudos expressam preocupação com o impacto que o federalismo pode ter sobre o desempenho econômico ${ }^{8}$ e se contrapõem frontalmente aos que sustentam que aquele induziria crescimento econômico. Para isso, eles conduzem pesquisas empíricas para testar se o federalismo ${ }^{9}$, com seus níveis de governo autônomos, não acabaria gerando excesso de gasto (o chamado "overspending") e, caso essa hipótese se confirme, procuram identificar que mecanismo(s) estaria(m) por detrás desse resultado. Variações desses estudos procuram analisar se o federalismo produziria incentivos que dificultam a aprovação de reformas macroeconômicas pela União ou que geram indisciplina fiscal nos Estados - ambas de grande relevância para o presente estudo.

Charles M. TIEBOUT procurou conceber um modelo analítico que, emulando as condições de mercado, levaria à distribuição ótima de bens públicos. No fundo, o que parece estar em questão é o tamanho do Estado: a ideia é a de que esse se ajuste ao ponto ótimo nem mais, nem menos - às preferências dos cidadãos em termos de receitas (taxação) e despesas (serviços). Em Estados nos quais há mais de um nível de governo, supõe-se que muitos desses bens públicos sejam providos em nível local, por isso os cidadãos poderiam revelar suas preferências simplesmente mudando-se de uma localidade para outra: caso não estejam satisfeitos com a relação taxação/serviços da localidade onde vivem, podem mudar-se

\footnotetext{
${ }^{7}$ Tradução livre para: "Since bailouts are beneficial to the recipient but costly to taxpayers as a whole, the central government will wish to announce firmly ex ante that it is resolute - that it never prefers bailouts. For a number of reasons this commitment may not be credible ex post, however when defaults loom or schools are about to close." RODDEN, Jonathan A. The Dilemma of Fiscal Federalism: Grants and Fiscal Performance around the World, American Journal of Political Science, v. 46, n. 3, jul. 2002, p. 671.

${ }^{8}$ RODDEN, Jonathan; WIBBELS, Erik. Beyond the Fiction of Federalism: Macroeconomic Management in Multitiered Systems. World Politics, v. 54, n. 4, jul. 2002, pp. 526-527.

${ }^{9}$ Pesquisas empíricas recentes têm questionado a relevância da distinção entre Estados federativos e unitários para explicar diversos fenômenos de interesse, como a disciplina fiscal dos Estados. Para os adeptos de tal posicionamento, nesse caso o mais prudente seria desagregar os elementos que se supõe componham a estrutura de Estados federativos e procurar identificar os mecanismos institucionais que explicam o resultado observado. Infelizmente, não há espaço neste trabalho para desenvolver melhor esse fascinante debate. Sobre essa questão, vide: RODDEN, Jonathan A. The Dilemma of Fiscal Federalism: Grants and Fiscal Performance around the World, p. 683; ARRETCHE, Marta. Democracia, federalismo e centralização no Brasil. Rio de Janeiro: Editora FGV; Editora Fiocruz, 2012, pp. 77-78.
} 
para outra que melhor espelhe suas preferências ${ }^{10}$. Assim, o modelo pressupõe, entre outras coisas, que haja muitas localidades alternativas, que os cidadãos tenham pleno conhecimento dessas e sejam complemente móveis ${ }^{11}$ - o que o torna um tanto distante da realidade. Mas o importante é que, nele, ninguém se beneficiaria às custas de ninguém, ao menos não do ponto de vista territorial.

Os modelos do competitive federalism e do market-preserving federalism, referidos por James M. BUCHANAN e Barry R. WEINGAST, respectivamente, parecem ser aplicações dessa proposição ao federalismo. Para o primeiro, o modelo ideal seria aquele em que a União limita-se a garantir o livre mercado, ao mesmo tempo em que induz a concorrência entre os Estados, mas para isso seria preciso assegurar a mobilidade (exit option) ${ }^{12}$. Para o segundo, a competência para regular a economia deveria recair, primariamente, sobre os Estados, de modo que a própria concorrência entre esses levaria as autoridades estaduais a adotarem políticas econômicas mais eficientes ${ }^{13}$. Jonathan A. RODDEN e Susan ROSEACKERMAN, no entanto, reputam essa suposição um tanto irrealista: no mundo real da política, autoridades estaduais podem ter incentivos para adotar políticas ineficientes ${ }^{14}$. De todo modo, o que parece estar implícito nesses modelos é uma preocupação com a possibilidade de que alguém que não contribuiu para aquele nível de provisão de bens públicos possa vir a dele usufruir (o chamado "free-rider problem"). Outra preocupação é a de que alguém possa vir a sobre-explorar bens públicos, prejudicando os demais ("overfish the common pool"). A questão é que tanto um quanto o outro apontam exemplos históricos que, segundo eles, demonstrariam que o federalismo - nos moldes propostos - induziria crescimento econômico ${ }^{15}$, o que tem obviamente relevância empírica.

Como se verá adiante, os autores do referencial teórico deste estudo, por outro lado, estão preocupados com a possibilidade de o federalismo, na verdade, criar incentivos para que os Estados se comportem de maneira indisciplinada em matéria fiscal, procurando "empurrar"

\footnotetext{
${ }^{10}$ TIEBOUT, Charles. A Pure Theory of Local Expenditures. The Journal of Political Economy, v. 64, n. 5, out. 1956, p. 418.

${ }^{11}$ TIEBOUT, Charles. Obra citada, p. 419.

${ }^{12}$ BUCHANAN, James M. Federalism as an Ideal Political Order and an Objective for Constitutional Reform. Publius: The Journal of Federalism, v. 25, n. 2, inverno 1995, pp. 21-23.

${ }^{13}$ WEINGAST, Barry R. The Economic Role of Political Institutions: Market-Preserving Federalism and Economic Development. Journal of Law, Economics, \& Organization, v. 11, n. 1, abr. 1995, pp. 4-6.

${ }^{14}$ RODDEN, Jonathan A.; ROSE-ACKERMAN, Susan. Does Federalism Preserve Markets? Virginia Law Review, v. 83, n. 7, out. 1997, pp. 1531-1546.

${ }^{15}$ BUCHANAN, James M. Obra citada, p. 27; WEINGAST, Barry R. Obra citada, pp. 6-9.
} 
para todos a conta de suas políticas fiscais, gerando externalidades que poderiam afetar a estabilidade macroeconômica do país como um todo. Diante dessa possibilidade, como cogita Jonathan A. RODDEN, a União pode querer se antecipar e sinalizar aos Estados que não os socorrerá (no-bailout commitment $)^{16}$, caso esses decidam prosseguir com uma política fiscal inconsequente, o que significa que esses precisarão promover ajustes, elevando receitas ou cortando despesas, pois não poderão contar com a União em caso de quebra (hard budget constraints). Como se verá adiante, embora esses autores convirjam em muitos aspectos de suas análises, parece haver algumas nuances no que diz respeito à relevância do conceito de federalismo e da distinção binária entre Estados unitários e federativos para a explicação do fenômeno.

Apesar de encerrar seu artigo conclamando as pesquisas empíricas subsequentes a testarem como diferentes desenhos de Estados federativos afetariam os resultados ${ }^{17}$, Erik WIBBELS parece derivar, ao longo de seu trabalho, algumas características institucionais a partir de um conceito de federalismo. Ele chega, inclusive, a questionar se esses problemas poderiam ocorrer em Estados unitários, porque nesses as autoridades regionais responderiam ao governo central ${ }^{18}$. Como em Estados federativos, União e Estados prestam contas a eleitorados diferentes, ele supõe que os eleitores cobrem desempenho econômico somente daquela e não desses. Assim, o federalismo criaria incentivos para a divergência de políticas físcais dentro do país, o que geraria problemas de coordenação (collective action problems) e dificultaria a aprovação de reformas macroeconômicas pela União ${ }^{19}$. Por fim, o federalismo, segundo ele, também geraria excesso de gasto, uma vez que o eleitor desconheceria, por conta das transferências fiscais, o real custo de um bem público, o que o levaria a sobredemandá-lo (a chamada "ilusão fiscal") ${ }^{20}$.

Já para Jonathan A. RODDEN, a variável relevante não seria propriamente a distinção binária entre Estados federativos e unitários, mas sim determinadas regras relacionadas ao

\footnotetext{
${ }^{16}$ RODDEN, Jonathan A. The Dilemma of Fiscal Federalism: Grants and Fiscal Performance around the World, p. 671.

${ }^{17}$ WIBBELS, Erik. Federalism and the Politics of Macroeconomic Policy and Performance. American Journal of Political Science, v. 44, n. 4, out. 2000, p. 698.

${ }^{18}$ WIBBELS, Erik. Obra citada, p. 689.

${ }^{19}$ WIBBELS, Erik. Obra citada, p. 688.

${ }^{20}$ WIBBELS, Erik. Obra citada, p. 689.
} 
desenho fiscal do Estado (algumas delas, é verdade, associadas ao federalismo) ${ }^{21}$, como o sistema de transferências fiscais (ou seja, qual é o nível de dependência dos Estados de repasses da União) e os controles sobre o endividamento estadual (ou seja, qual é o nível de autonomia que os Estados têm para tomar empréstimos). Essas regras são encaradas como fatores institucionais determinantes para conferir maior ou menor credibilidade àquele compromisso da União de que não socorrerá Estados indisciplinados. Se, no entanto, essa ameaça soar como um blefe aos ouvidos dos Estados, esses podem prever que serão socorridos pela União e não se ajustarão. Como observa Jonathan A. RODDEN:

Quando o governo central está profundamente envolvido no financiamento dos governos subnacionais, aquele assume obrigações morais, políticas e práticas que tornam difícil que se comprometa a dizer 'não' a entidades que excedem gasto, geram déficits insustentáveis e demandam resgates ${ }^{22}$.

Nesse mesmo sentido, Afonso S. BEVILAQUA:

Uma outra característica do problema do resgate de dívidas estaduais é o fato de que, sob determinadas condições, ainda que o governo federal saiba que a situação financeira precária dos Estados pode ser atribuída ao comportamento inconsequente desses, aquele pode decidir resgatá-los. Um resgate pode ser concedido porque o governo federal se importa com o bem-estar dos cidadãos dos Estados, porque há vantagens políticas associadas à decisão de socorrê-los, ou por causa da extensão de externalidades negativas no resto do país caso esse resgate não seja feito. ${ }^{23}$

Embora o referencial teórico não contemple explicitamente a chamada Corte Suprema, a verdade é que o recurso a essa não é de modo algum descartado por seus autores. A teoria das arenas de veto, na formulação de Ellen M. IMMERGUT, parte do pressuposto de que os atores conhecem as regras e as preferências das arenas e podem calcular os resultados. Com base nessa previsão, adaptam suas estratégias na tentativa de potencializar suas chances de vitória, deslocando a decisão de uma arena para outra ${ }^{24}$, caso essa lhe pareça mais favorável do que aquela. Desse modo, a Corte Suprema pode ser considerada como uma

\footnotetext{
${ }^{21}$ RODDEN, Jonathan A. The Dilemma of Fiscal Federalism: Grants and Fiscal Performance around the World, p. 683.

${ }^{22}$ Tradução livre para: "When the central government is heavily involved in financing subnational governments, it incurs moral, political, and practical obligations that make it difficult to commit to 'say no' to entities that overspend, generate unsustainable deficits, and demand bailouts". RODDEN, Jonathan A. The Dilemma of Fiscal Federalism: Grants and Fiscal Performance around the World, p. 671.

${ }^{23}$ Tradução livre para: "A distinct characteristic of the state debt bailout problem is the fact that under some specific conditions, even if the federal government knows that the states precarious financial situation can be attributed to their own reckless behavior, it may choose to bail them out. A bailout may be extended because the federal government cares about the welfare of states' citizens, because there are political benefits associated with the decision of rescuing states, or because of the scope for negative externalities on the rest of the country in the absence of a bailout." BEVILAQUA, Afonso S. Obra citada, p. 30.

${ }^{24}$ IMMERGUT, Ellen M. Institutions, Veto Points, and Policy Results: a Comparative Analysis of Health Care. Journal of Public Policy, v. 10, n. 4, out.-dez. 1990, pp. 397-398.
} 
"arena de veto" desde que, segundo as "regras do jogo", tenha autoridade para obstruir (ex ante) ou para reverter (ex post) a aprovação de uma medida nas arenas convencionais. Para que isso possa ocorrer, primeiro é preciso que essa seja acionada por um dos atores autorizados a tanto, pois uma de suas características é a inércia (só age se provocada). A Constituição brasileira confere ao STF a competência para julgar as causas e dirimir os conflitos envolvendo entes federativos (art. 102, I, " $f$ '), bem como autorizou governadores a proporem ações de controle de constitucionalidade (art. 103, V). Uma singela contribuição que o presente estudo pretende fazer para esse ramo da literatura é demonstrar que o recurso ao STF por Estados que se sentiram prejudicados ou que foram derrotados, em matéria fiscal, em outras arenas do processo decisório foi mais frequente do que se poderia supor e que decisões tomadas nessa arena também podem afetar a credibilidade de medidas de ajuste fiscal.

\title{
3 UNIÃO RESGATA ESTADOS SUCESSIVAS VEZES, MAS SE COMPROMETE A NÃO MAIS OS SOCORRER (1989-2001)
}

\begin{abstract}
O Brasil passou por três crises de dívidas estaduais severas entre os anos 1980 e 2000. Em todos esses episódios, os Estados - que já enfrentavam situações fiscais precárias com níveis altos de gasto com pessoal e com o pagamento de juros -

foram levados, por choques exógenos, a crises de serviço da divida. Em todos os casos, sua primeira reação foi demandar resgate do governo central e, em todos os casos, esse respondeu com medidas para assumir dívidas estaduais.
\end{abstract}

(Jonathan A. RODDEN) $)^{25}$

Segundo Jonathan A. RODDEN, baseado em dados levantados por Afonso S. BEVILAQUA, as dívidas de Estados e Municípios brasileiros que, em meados da década de 1960, não chegavam a 1\% do PIB brasileiro, ultrapassaram os 14\% em 1998, chegando a representar um risco à estabilidade macroeconômica do país ${ }^{26}$. A literatura parece convergir na identificação da década de 1970 como a origem do endividamento de Estados e Municípios no Brasil. Para Fernando REZENDE e José Roberto R. AFONSO, a centralização,

\footnotetext{
${ }^{25}$ Tradução livre para: "Brazil has experienced three major state-level debt crisis between the 1980s and 2000. In each of the crisis episodes, the states - already facing precarious fiscal situations with high levels of spending on personnel and interest payments - were pushed into debt-servicing crisis by exogenous shocks. In each case, their first reaction was to demand bailouts from the central government, and in each case the federal government responded by taking measures to assume state debts." RODDEN, Jonathan A. Hamilton's Paradox: the promise and peril of fiscal federalism. New York: Cambridge University Press, 2006, pp. 188-189.

${ }^{26}$ RODDEN, Jonathan A. Hamilton's Paradox: the promise and peril of fiscal federalism, pp. 188, 205.
} 
característica do regime militar, teria surtido efeitos paradoxais: de um lado, restringiu a autonomia dos Estados; de outro, contribuiu para seu endividamento ${ }^{27}$. É que, com a escassez de recursos, reflexo da centralização, os Estados teriam passado a depender de crédito para financiar seus investimentos. Em um primeiro momento, esse crédito dependia em geral da autorização de e era obtido junto a instituições federais. No início da década de 1980, no entanto, o governo federal teria passado a estimular os Estados a captarem empréstimos no exterior ${ }^{28}$.

Com o fim do regime militar e a aprovação da Constituição de 1988, foi aprovada a Lei $n^{o} 7.976 / 1989$, pela qual o governo federal assumiu e refinanciou por 20 anos, com um período de carência de 5 anos, as dívidas externas de Estados e Municípios, conforme previsto na lei. A lei estendeu aos Estados condições semelhantes, no tocante a correção monetária e juros, aos respectivos contratos externos da União (art. $3^{\circ}$, I); previu, inclusive, que se a União viesse a obter, em relação a esses contratos, novos benefícios em eventuais negociações com credores externos, tais benefícios deveriam ser repassados aos Estados (art. $4^{\circ}$ ). A lei vinculou, em garantia desses contratos, as quotas ou parcelas previstas no art. 159 da Constituição da República (ou seja, receitas partilhadas de Estados e Municípios), como forma de assegurar seu cumprimento (art. $3^{\circ}$, II). Segundo Afonso S. BEVILAQUA, em valores nominais os Estados do Sudeste teriam concentrado a maior parte do refinanciamento, mas como parcela do PIB estadual os Estados do Nordeste teriam sido os grandes beneficiados ${ }^{29}$.

Ainda segundo Afonso S. BEVILAQUA, as dívidas estaduais e municipais que, em 1991, correspondiam a 7,5\% do PIB passaram para 9,3\% em 1993, período em que os títulos emitidos por Estados teriam se tornado sua principal fonte de financiamento, respondendo por mais de $70 \%$ do crescimento de suas dívidas ${ }^{30}$. A situação chegou a tal ponto que Estados e Municípios foram proibidos de emitir novos títulos até o final de 1999 pela Emenda Constitucional $n^{\circ} 3 / 1993$ (art. $5^{\circ}$ ). Paralelamente, foi aprovada a Lei $n^{o} 8.727 / 1993$, pela qual foram refinanciadas por 20 anos as dívidas que Estados e Municípios tinham com a

\footnotetext{
27 AFONSO, José Roberto R; REZENDE, Fernando. O (des)controle do endividamento de Estados e Municípios: análise crítica das normas vigentes e propostas de reforma. Textos para discussão interna, n. 132. Rio de Janeiro: IPEA, jan. 1988, p. 4.

${ }^{28}$ BEVILAQUA, Afonso S. Obra citada, p. 5.

${ }^{29}$ BEVILAQUA, Afonso S. Obra citada, p. 7.

${ }^{30}$ BEVILAQUA, Afonso S. Obra citada, p. 11.
} 
União, conforme previsto na lei. Por um lado, a lei limitou o comprometimento das receitas estaduais para pagamento das prestações a um teto estabelecido pelo Senado Federal, sendo que o resíduo eventualmente formado pelas parcelas não pagas dessas prestações seria refinanciado por até 10 anos (art. $2^{\circ}$ ). Por outro, vinculou mais receitas, em garantia desses contratos, abrangendo as previstas nos arts. 155-158 e 159, I, " $a$ " e " $b$ ”, II, da Constituição da República (ou seja, receitas próprias e partilhadas de Estados e Municípios) (art. $3^{\circ}$ ). Segundo Afonso S. BEVILAQUA, teriam sido novamente os Estados do Sudeste que concentraram a maior parte dos recursos refinanciados, mas como parcela do PIB estadual teriam sido os do Nordeste os que mais se beneficiaram ${ }^{31}$.

A literatura também parece convergir quanto ao diagnóstico de que, com a queda da inflação e as altas taxas de juros praticadas no início do Plano Real, os Estados foram forçados a se ajustar. Esse impacto do Plano Real sobre a situação fiscal dos Estados é descrito por Jonathan A. RODDEN como uma externalidade da política fiscal adotada pela União: “Os Estados também enfrentaram desafios exógenos por causa da taxa de juros, muito de sua dívida era vulnerável a flutuações de curto prazo na taxa de juros" ${ }^{32}$. Os títulos estaduais passaram, então, a comprometer a liquidez de bancos controlados por Estados ${ }^{33}$, o que preocupava o governo federal (especialmente a situação do BANESPA, visto como "too big to fail") ${ }^{34}$. Foi, então, que esse lançou, por meio da Medida Provisória (MPv) no 1.514/1996, o chamado "Programa de Incentivo à Redução do Setor Público Estadual na Atividade Bancária (PROES)", visando à privatização ou à transformação de bancos estaduais em instituições não-financeiras ou agências de fomento. De acordo com informações da Revista "Em Discussão!” do Senado Federal, em edição dedicada ao tema das dívidas estaduais, ao todo 32 instituições (inclusive o BANESPA) foram reestruturadas com base no PROES ${ }^{35}$.

No ano seguinte, o governo federal instituiu, por meio da $\operatorname{MPv} \mathrm{n}^{\circ}$ 1.560-8/1997, posteriormente convertida na Lei $n^{o}$ 9.496/1997, o chamado "Programa de Apoio à Reestruturação e ao Ajuste Fiscal dos Estados" (conhecido por alguns como PAF), prevendo

\footnotetext{
${ }^{31}$ BEVILAQUA, Afonso S. Obra citada, p. 14.

${ }^{32}$ Tradução livre para: "The states also faced exogenous challenges because of interest rates; much of their debt was vulnerable to short-term interest rate fluctuations". RODDEN, Jonathan A. Hamilton's Paradox: the promise and peril of fiscal federalism, p. 207.

${ }^{33}$ BEVILAQUA, Afonso S. Obra citada, p. 14.

${ }^{34}$ RODDEN, Jonathan A. Hamilton's Paradox: the promise and peril of fiscal federalism, p. 208.

${ }^{35}$ BRASIL. Em discussão! Revista de Audiências Públicas do Senado Federal, n. 16. Dívida Pública: uma equação difícil. Brasília: Senado Federal, jul. 2013, p. 15.
} 
metas e objetivos específicos a serem alcançados pelos Estados e pelo Distrito Federal (art. $2^{\circ}$ ), e assumindo e refinanciando suas dívidas, conforme previsto na lei. A lei determina que os contratos de refinanciamento devem ser pagos em até 30 anos, com prestações mensais calculadas pela "Tabela Price", com juros de, no mínimo, 6\% ao ano e correção monetária pelo IGP-DI (FGV) (art. $3^{\circ}$ ). Em tese, como observou Afonso S. BEVILAQUA, tais contratos seriam subsidiados: "Como a taxa de juros de $6 \%$ é substancialmente inferior à taxa de juros real, com a qual o governo federal provavelmente financiará sua dívida ao longo do período contratual, os contratos envolvem um subsídio na dívida reestruturada." ${ }^{36}$ A lei estabelece que, dentre as garantias dos referidos contratos, devem incluir-se obrigatoriamente as receitas previstas nos arts. 155, 157 e 159, I, “ $a$ ” e II, da Constituição da República (ou seja, receitas próprias e partilhadas dos Estados) (art. $4^{\circ}$ ). Por fim, a lei também autoriza que os referidos contratos prevejam um limite de comprometimento da receita líquida real (RLR) para o pagamento do serviço da dívida (art. 5-6 ${ }^{\circ}$, sendo que eventual resíduo poderá ser renegociado por até 10 anos $\left(\operatorname{art} .6^{\circ}, \S 5^{\circ}\right)$.

De acordo com informações da Revista “Em Discussão!” do Senado Federal, entre 1997 e 1999 todos os Estados (com exceção de Amapá e Tocantin s) e o Distrito Federal celebraram contratos de refinanciamento com a União com base na Lei n ${ }^{\circ} 9.496 / 1997^{37}$. Segundo Mônica MORA e Fabio GIAMBIAGI, os Estados de São Paulo, Rio de Janeiro, Minas Gerais e Rio Grande do Sul, que eram os que mais haviam obtido recursos via títulos públicos, concentraram a maior parte das dívidas refinanciadas ${ }^{38}$. Em 1999, após seu Governador ter anunciado a moratória da dívida com a União, o Estado de Minas Gerais ajuizou no STF a Petição (PET) $n^{o} 1.665$ em face da União, questionando a constitucionalidade de cláusulas do contrato de refinanciamento e pleiteando a obtenção de liminar para determinar a suspensão e a restituição de valores bloqueados pela União e que essa se abstivesse de se apropriar de valores do Estado, em decorrência do inadimplemento do contrato. O pedido, porém, foi indeferido pelo Min. Moreira Alves, ao fundamento de que a cláusula contratual que autoriza o bloqueio em caso de inadimplemento teria assento na Constituição (arts. 160 e 167, IV).

\footnotetext{
${ }^{36}$ Tradução livre para: "Since the 6 percent real interest rate is substantially lower than the real interest rates at which the federal government will likely finance its debt during the contract period, the contracts involve a subsidy on the restructured debt." BEVILAQUA, Afonso S. Obra citada, p. 25.

${ }^{37}$ BRASIL. Em discussão! Revista de Audiências Públicas do Senado Federal, n. 16. Dívida Pública: uma equação difícil, p. 7.

38 GIAMBIAGI, Fabio; MORA, Mônica. Federalismo e endividamento subnacional: uma discussão sobre a sustentabilidade da dívida estadual e municipal. Texto para discussão, n. 1142. Rio de Janeiro: IPEA, dez. 2005 , p. 5.
} 
Interessante observar que, em 2003, o Rio de Janeiro chegou a obter liminar, na Ação Cautelar (AC) $n^{\circ}$ 6, com fundamento em um suposto "estado de necessidade", para a restituição de valores que haviam sido bloqueados nas contas do Estado. Mas essa decisão foi logo tornada sem efeito ante a não-comprovação pelo Estado da referida situação.

Nos anos seguintes à celebração dos contratos de refinanciamento com base na Lei $\mathrm{n}^{\mathbf{o}}$ 9.496/1997, o governo federal conseguiu mais duas importantes vitórias: primeiro, a aprovação pelo Congresso Nacional da Lei Complementar (LC) $\mathrm{n}^{\circ}$ 101/2000 (LRF), que contém importantes disposições que regulam o gasto dos entes federativos e punem gestores indisciplinados; e, segundo, a aprovação pelo Senado Federal da Resolução $n^{\circ} 40 / 2001$, que estipula limites globais da dívida pública dos Estados, Distrito Federal e Municípios. Segundo Mônica MORA e Fabio GIAMBIAGI, a LRF pode ser considerada um "desdobramento" do $\mathrm{PAF}^{39}$. A lei estabelece, por exemplo, que a despesa total com pessoal não pode ultrapassar o limite de $50 \%$ da receita corrente líquida (RCL) para a União e de $60 \%$ para Estados e Municípios (arts. 18-20). A Resolução do Senado Federal, por sua vez, limita a dívida consolidada líquida dos Estados e do Distrito Federal ao correspondente a duas vezes a sua respectiva receita corrente líquida (art. $\left.3^{\circ}, \mathrm{I}\right)$.

De especial importância para o presente estudo, é o art. 35 da $L R F^{40}$ que, em regra, proíbe a realização de operações de crédito entre entes federativos, inclusive como "novação, refinanciamento ou postergação" de dívidas pré-existentes. Em suma: após celebrar os contratos de refinanciamento com base na Lei $n^{\circ}$ 9.496/1997, a União tratou de deixar claro aos Estados que esses precisariam se ajustar, pois não poderiam contar com novos resgates no futuro. Vê-se, assim, que no Brasil entendeu-se que, para que o compromisso ex ante da União de não socorrer Estados endividados gozasse de credibilidade, era preciso formalizá-lo em dispositivo de lei (no caso, de lei complementar). Após a edição da LRF, o Governador de Minas Gerais entrou com a Ação Direta de Inconstitucionalidade (ADI) $n^{o}$ 2.250, questionando no STF a constitucionalidade do referido dispositivo, por violação ao

\footnotetext{
${ }^{39}$ GIAMBIAGI, Fabio. MORA, Mônica. Obra citada, p. 5.

${ }^{40}$ Eis o que dispõe o caput do referido dispositivo: "Art. 35. É vedada a realização de operação de crédito entre um ente da Federação, diretamente ou por intermédio de fundo, autarquia, fundação ou empresa estatal dependente, e outro, inclusive suas entidades da administração indireta, ainda que sob a forma de novação, refinanciamento ou postergação de dívida contraída anteriormente." BRASIL. Lei Complementar $n^{o} 101$. Brasília: Congresso Nacional, 4 mai. 2000. Ressalte-se apenas que a própria lei prevê exceções a essa regra.
} 
princípio federativo. O pedido de liminar para suspender sua eficácia, no entanto, foi indeferido pela unanimidade dos Ministros em 2003.

Afonso S. BEVILAQUA conclui que os achados de sua pesquisa oferecem suporte para a hipótese de que a recorrência de resgates pela União esteve associada à indisciplina fiscal dos Estados no Brasil ao longo dos anos 1990:

Considerando apenas as operações de resgate mais importantes, os Estados brasileiros foram socorridos três vezes pelo governo federal na última década. Durante o mesmo período, o desempenho fiscal desses piorou consideravelmente e tornou-se um fator importante na deterioração observada na situação fiscal consolidada do setor público após o Plano Real. ${ }^{41}$

Francisco RIGOLON e Fabio GIAMBIAGI, por sua vez, asseveram que:

[a]s sucessivas renegociações das dívidas estaduais criaram, por um lado, um problema de perigo moral, uma vez que incentivaram o endividamento excessivo dos estados no presente, apoiado na crença de socorro financeiro no futuro. Por outro, elas contribuíram para o progressivo aperfeiçoamento dos mecanismos de controle das finanças estaduais. $^{42}$

\section{ESTADOS DESAFIAM O COMPROMISSO DA UNIÃO NO CONGRESSO NACIONAL E CONSEGUEM RENEGOCIAR ANTIGAS DÍVIDAS (2013-2016)}

[...] o governo central aprovou reformas na tentativa de reforçar compromissos de não-resgate, mas dadas as lições aprendidas com seus passos em partidas anteriores do jogo, governos estaduais continuaram a tomar decisões fiscais como se estivessem jogando contra um governo central não comprometido.

(Jonathan A. RODDEN) $)^{43}$

Anos após a celebração dos contratos de refinanciamento das dívidas estaduais com a União com base na Lei $n^{\circ}$ 9.496/1997 e a aprovação da LRF, estabelecendo parâmetros mais rigorosos de gestão fiscal para os entes federativos, a avaliação de muitos especialistas a

\footnotetext{
${ }^{41}$ Tradução livre para: "Counting only major bailout operations, Brazilian states were rescued three times by the federal government in the last decade. During the same period, their fiscal performance worsened considerably and they became a major factor in the observed deterioration in the consolidated public sector fiscal stance after the Real Plan." BEVILAQUA, Afonso S. Obra citada, p. 34.

${ }^{42}$ GIAMBIAGI, Fabio; RIGOLON, Francisco. A renegociação das dívidas e o regime fiscal dos Estados. In: GIAMBIAGI, Fabio; MOREIRA, Maurício Mesquita (Orgs.) A economia brasileira nos anos 90 . Rio de Janeiro: BNDES, 1999, p. 127.

${ }^{43}$ Tradução livre para: "[...] the central government has promulgated reforms attempting to reassert no-bailout commitments; but given the lessons learned from the central government's moves in previous plays of the game, state governments clearly continue to make fiscal decisions as if they are playing against a noncommitted central government." RODDEN, Jonathan A. Hamilton's Paradox: the promise and peril of fiscal federalism, p. 8 .
} 
respeito das reformas promovidas pelo ex-Presidente FHC era bastante positiva ${ }^{44}$. Maria Rita LOUREIRO ressalta que esse teria sido bem-sucedido ao obter coesão em torno de sua agenda de ajuste fiscal, que teria contado com o suporte não só de órgãos do próprio Poder Executivo, como com o comprometimento do Senado Federal e a chancela do Judiciário ${ }^{45}$. Mas, como se verá adiante, esse quadro não perdurou por muito tempo: cerca de quinze anos depois, Estados já demostravam insatisfação com os termos do resgate e passaram a pressionar pela sua revisão.

Segundo informações da Revista “Em Discussão!", aqueles contratos de refinanciamento celebrados com base na Lei $n^{\circ}$ 9.496/1997 que, como visto, eram a princípio subsidiados pela União, teriam deixado de ser vantajosos para os Estados ${ }^{46}$. Vale lembrar que o índice de correção monetária adotado nesses contratos foi o IGP-DI (FGV). Como, à época da celebração dos contratos, o governo federal praticava uma política de taxa básica de juros (Selic) elevada, naquele contexto o IGP-DI (FGV) era mais baixo e, portanto, mais favorável aos devedores. Com a mudança na política do governo federal, reduzindo a taxa básica de juros, exceto em 2009, a Selic passou a ser mais baixa que o IGP-DI (FGV) desde 2007, sendo que o IPCA foi mais baixo que ambos ao longo do período de 1997-201247. Ressalte-se que, anos depois, o próprio Ministério da Fazenda reconheceria que:

[a]o realizar análise da evolução histórica dos indexadores dos contratos da dívida celebrados entre a União, Estados, o Distrito Federal e Municípios [...], constata-se que

\footnotetext{
${ }^{44}$ Nesse sentido: "O esforço empreendido pelo governo federal e o alto custo da renegociação foram compensadores: as relações financeiras do governo federal com os estados estão mais organizadas e mais transparentes. A maioria dos estados ajustou suas finanças públicas, promoveu reformas administrativas e atingiu um patamar mais elevado de administração financeira mais eficiente e com responsabilidade fiscal. A despeito das dificuldades e desafios que ainda persistem, a gestão das finanças públicas dos estados brasileiros evoluiu de maneira significativa. Foi um grande avanço." BOUERI, Rogério; PIANCASTELLI, Marcelo.. Dívida dos Estados 10 anos depois. Texto para discussão, n. 1366. Rio de Janeiro: IPEA, dez. 2008, p. 40; e "A privatização e/ou liquidação dos bancos estaduais ocorreu com êxito no âmbito do Proes. [...] Desse modo, eliminou-se um importante instrumento para o financiamento de déficits. Essa medida contribuiu não somente para o equilíbrio intertemporal das finanças estaduais, mas também para a estabilidade macroeconômica. Por fim, o ajuste fiscal implementado pelos estados [...] sobre o qual se apoiou o Programa de Reestruturação Fiscal e Financeira [...], foi igualmente bem-sucedido, dada a sua magnitude (com a inflexão de um resultado primário negativo entre 1995 e 1998 para o atual superávit de aproximadamente 1\% do PIB [...]).” GIAMBIAGI, Fabio; MORA, Mônica. Obra citada, pp. 19-20.

${ }^{45}$ LOUREIRO, Maria Rita. Instituições, política e ajuste fiscal: o Brasil em perspectiva comparada. Revista Brasileira de Ciências Sociais, v. 16, n. 47, out. 2011, pp. 89-90.

${ }^{46}$ BRASIL. Em discussão! Revista de Audiências Públicas do Senado Federal, n. 16. Dívida Pública: uma equação difícil, p. 3.

${ }^{47}$ BRASIL. Em discussão! Revista de Audiências Públicas do Senado Federal, n. 16. Dívida Pública: uma equação difícil, pp. 8 e 15. Vide gráfico da p. 12 com a evolução dos índices de reajuste no período em questão.
} 
as taxas acordadas foram favoráveis aos estados em um primeiro momento, tiveram impacto neutro entre 1999 e 2012 e, a partir de então, se tornaram desfavoráveis. ${ }^{48}$

Como se vê, os Estados argumentavam basicamente que, naquele momento, a União estaria se beneficiando com essa mudança, o que reverteria conquistas por esses alcançadas em 1997. Mônica MORA e Fabio GIAMBIAGI explicam que “[o] descolamento do IGP-DI do IPCA funcionou com um aumento da taxa de juros [...] e aproximou a taxa paga pelos entes da federação ao preço de captação do governo federal, reduzindo o subsídio concedido [...]" ${ }^{49}$. Reforçava esse argumento a interpretação de que teria sido uma externalidade da política fiscal do governo federal (a redução da taxa básica de juros) que teria provocado essa situação. Registre-se apenas que, na interpretação de Marcos MENDES e Daniel CARVALHO, na realidade teria sido justamente o sucesso do ajuste fiscal (a que foram submetidos os Estados por força do PAF e da LRF) que teria criado condições para o surgimento de uma conjuntura macroeconômica propícia à redução da taxa básica de juros ${ }^{50}$. Com a aprovação da $L C n^{o} 148 / 2014$, o pleito desses Estados parecia ter sido atendido. A lei autorizou a União a celebrar com Estados termos aditivos nos contratos de refinanciamento da Lei $n^{\circ}$ 9.496/1997, reduzindo os juros para 4\% ao ano e alterando o indexador da correção monetária para o IPCA, encargos esses limitados à taxa referencial da Selic para títulos federais (art. $2^{\circ}$ ). A lei também autorizou a União a conceder um desconto retroativo no valor das dívidas correspondente à diferença entre o saldo devedor em $1^{\circ}$ de janeiro de 2013 e o recalculado com base na variação acumulada da Selic desde a celebração dos contratos (art. $\left.3^{\circ}\right)$.

Como, passados meses da aprovação da referida lei, a União não havia tomado nenhuma medida concreta para celebrar com os Estados os referidos termos aditivos, foi aprovada a $L C n^{\circ} 151 / 2015$, alterando a redação de dispositivos da $L C n^{\circ} 148 / 2014$, de modo a deixar claro que a União não só estava autorizada a como teria de celebrá-los, fixando inclusive um prazo de até 31 de janeiro de 2016, ao término do qual os Estados já poderiam, "independentemente de regulamentação", efetuar os pagamentos das prestações nos termos definidos na LC n ${ }^{o}$ 148/2014. O governo federal editou, então, o Decreto $n^{o}$ 8.616/2015,

\footnotetext{
48 BRASIL. Atualização dos contratos de refinanciamento da dívida celebrados entre a União, Estados, o Distrito Federal e Municípios. Nota técnica. Brasília: Ministério da Fazenda, abr. 2016.

${ }^{49}$ GIAMBIAGI, Fabio; MORA, Mônica. Obra citada, p. 35.

${ }^{50}$ CARVALHO, Daniel Melo Nunes de; MENDES, Marcos José. O pleito do Estado de Santa Catarina junto ao STF para revisão de sua dívida com a União. Boletim Legislativo, n. 47. Núcleo de Estudos e Pesquisas da Consultoria Legislativa, abr. 2016, p. 4.
} 
regulamentando a LC n ${ }^{\circ}$ 148/2014 e estabelecendo "procedimentos" para a celebração dos respectivos termos aditivos (art. $2^{\circ}, \S 1^{\circ}$ ), o que incluía algumas condições como a necessidade de desistência de eventuais ações judiciais e renúncia a quaisquer alegações de direito relativas à dívida ou contrato objeto do termo aditivo (inc. II); etc. Importante observar que o art. $2^{\circ}, \S 3^{\circ}$, do referido decreto explicita que o art. $35 d a L R F$, que proíbe a realização de operações de crédito entre entes federativos, havia sido excepcionado pelo disposto na LC no 148/2014. Como se vê, bastou aprovar uma nova lei de mesmo status (lei complementar) ${ }^{51}$, abrindo uma exceção, para que aquele compromisso ex ante pudesse ser afastado ex post.

Inconformado com as condições estabelecidas pelo Decreto $\mathrm{n}^{\circ}$ 8.616/2015 que segundo ele agravariam sua situação, o Estado do Alagoas ajuizou no STF a Ação Cível Originária $(\mathrm{ACO}) \mathrm{n}^{\circ} 2.805$, em face da União, pleiteando fosse dispensado de cumpri-las para poder celebrar termo aditivo com a União. O pedido de liminar foi parcialmente deferido pela Miñ $^{a}$ Cármen Lúcia ${ }^{52}$, para afastar somente a condição estabelecida no inciso II. Com base nesse precedente, a Ministra concedeu, dias depois, na ACO $\mathrm{n}^{\circ} 2.810$ liminar semelhante ao Estado do Rio de Janeiro. O Partido dos Trabalhadores (PT) também ajuizou a Ação de Descumprimento de Preceito Fundamental (ADPF) $n^{o}$ 382, questionando o referido decreto, alegando que esse havia inovado ao estabelecer condições não previstas na lei. Novamente, com base nesses precedentes, a Ministra ${ }^{53}$ concedeu parcialmente a liminar, agora para suspender a eficácia dos incisos I e II do $\S 1^{\circ}$ do art. $2^{\circ}$ do Decreto $n^{\circ} 8.616 / 2015$. Após essas decisões, o governo federal resolveu consultar a Advocacia-Geral da União (AGU) que elaborou parecer ${ }^{54}$ em que, citando essa decisão, recomendou a revogação de tais condições, o que foi feito por meio do Decreto $n^{o} 8.665 / 2016$.

\footnotetext{
51 “[...] Decidiu-se, então, pela renegociação dos contratos. Todavia, a existência da vedação a novos refinanciamentos, imposta pela $L R F$, tornou necessária a edição de lei complementar para abrir exceção à regra do mencionado diploma legal, o que levou à promulgação da LCP $n^{\circ}$ 148." MENDES, Marcos José; CARVALHO, Daniel Melo Nunes de. Obra citada, p. 4.

52 "[...] não pode o direito dar com uma mão e tirar com a outra, quer dizer, oferecer a possibilidade de repactuar a dívida do ente federado com a União para melhorar as condições do ajuste e exigir a piora da situação do contratante, mesmo quando superado por decisão judicial aquele anterior estado, para obter aquela melhoria [...]" Trecho da decisão proferida pela Ministra do STF Cármen Lúcia nos autos da ACO no 2.805/DF, ajuizada pelo Estado do AL em face da União, publicada no Diário de Justiça eletrônico (DJe) no 021/2016, que foi divulgado no dia 03/02/2016 e publicado no dia 04/02/2016, p. 14.

53 "Tornar exigência insuperável o que não pode ser cumprido no prazo fixado normativamente é tornar inoperante a norma e frustrado o direito que nela se contém, donde a sua insustentabilidade jurídica porque esvaziado fica o ditame e ineficaz a regra." Trecho da decisão proferida pela Ministra do STF Cármen Lúcia nos autos da ADPF $n^{\circ}$ 382/DF, ajuizada pelo PT, publicada no DJe $n^{\circ}$ 019/2016, que foi divulgado no dia 01/02/2016 e publicado no dia $02 / 02 / 2016$, p. 76.

${ }^{54}$ Conf. Parecer DENOR/CGU/AGU n ${ }^{\circ} 005 / 2016$, que abrange os incisos I, II e IV do art. $2^{\circ}, \S 1^{\circ}$, do referido Decreto.
} 


\section{APÓS UM ESTADO OBTER UMA LIMINAR NO STF, OUTROS ADOTAM A MESMA ESTRATÉGIA E CONSEGUEM NOVAS CONCESSÕES DA UNIÃO (2016-2017)}

Nesse mesmo ano, instaurou-se uma nova controvérsia judicial agora em torno da forma de cálculo dos juros da dívida: se por juros compostos, como seria a praxe no Brasil, ou por juros simples, como pretendiam alguns Estados. A celeuma surgiu com a impetração, perante o STF, pelo Estado de Santa Catarina do Mandado de Segurança (MS) $n^{\circ}$ 34023/DF, questionando a metodologia de cálculo estabelecida novamente no Decreto $\mathrm{n}^{\circ}$ 8.616/2015 que, na visão do impetrante, não refletiria o que havia sido aprovado pelo Congresso Nacional. Segundo esse, a LC n ${ }^{\circ}$ 148/2014 - diferentemente do decreto que a regulamenta - não preveria a capitalização dos juros. Em 26/02/2016, o Min. Edson Fachin, relator da ação, negou seguimento ao mandado de segurança e julgou prejudicado o pedido de liminar; porém, em 07/04/2016, o Plenário do Tribunal proveu, por maioria ${ }^{55}$, o recurso interposto pelo Estado e concedeu a liminar pleiteada, determinando que os impetrados se abstivessem de impor sanções ao Estado, sobretudo as previstas em cláusula contratual, bem como de efetuar bloqueios de recursos de transferências federais. Logo na sequência, outros Estados se somaram a Santa Catarina e passaram a impetrar no STF mandados de segurança com pedidos semelhantes. Foram impetrados 18 mandados de segurança, por 15 Estados (de todas as regiões do país), pelo Distrito Federal e por 1 Município $^{56}$, cujos pedidos de liminar foram deferidos ou parcialmente deferidos, com base no princípio da isonomia: "Enquanto se aguarda a iminente solução da questão pelo Plenário [...], considero que o Estado impetrante não deve ficar

\footnotetext{
${ }^{55} \mathrm{O}$ relator, em seu voto minoritário, chamou atenção para o fato de que essa questão já havia sido aventada durante a tramitação da LC no 148/2014 no Congresso Nacional, quando da rejeição pelo Plenário do Senado Federal da Emenda Substitutiva $n^{\circ} 6$ e da Emenda $n^{\circ} 7$ que propunham a eliminação da cobrança de juros nesses contratos, sob a justificativa de que a prática do anatocismo (juros sobre juros) seria considerada ilegal pelo STF. Vide justificação do Sen. Randolfe Rodrigues (PSOL/AP), autor das referidas proposições, que consta no Diário do Senado Federal no 212/2013, publicado no dia 19/12/2013, pp. 98515-98524.

${ }^{56}$ Por ordem cronológica da data de impetração dos respectivos MS: 1) MS nº 34023/DF (SC), Rel. Min. Edson Fachin; 2) MS no 34110/DF (RS), Rel. Min. Edson Fachin; 3) MS no 34122/DF (MG), Rel. Min. Edson Fachin; 4) MS no 34123/DF (AL), Rel. Min. Luiz Fux; 5) MS no 34126/DF (Bauru/SP), Rel ${ }^{a}$ Min $^{\text {a }}$ Rosa Weber; 6) MS $n^{\circ}$ 34132/DF (PA), Rel. Min. Marco Aurélio; 7) MS no 34135/DF (SP), Rel. Min. Celso de Mello; 8) MS nº 34137/DF (RJ), Rel. Min. Roberto Barroso; 9) MS nº 34141/DF (MS), Rel. Min. Edson Fachin; 10) MS no 34143/DF (GO), Rel. Min. Roberto Barroso; 11) MS no 34149/DF (SE), Rel. Min. Marco Aurélio; 12) MS no 34151/DF (BA), Rel ${ }^{\mathbf{a}}$ Min ${ }^{a}$ Cármen Lúcia; 13) MS no 34152/DF (MT), Rel. Min. Marco Aurélio; 14) MS no 34154/DF (DF), Rel ${ }^{a}$ Min $^{a}$ Rosa Weber; 15) MS n 34163/DF e 34164/DF (AP), Rel. Min. Dias Toffoli e Cármen Lúcia, respectivamente; 16) MS no 34168/DF (PE), $\operatorname{Rel}^{\mathrm{a}}$ Min $^{\mathrm{a}}$ Rosa Weber; e 17) MS nº 34186/DF (PR), Rel. Min. Dias Toffoli.
} 
em situação melhor nem pior relativamente aos demais Estados que têm acionado esta Corte. $" 57$

Embora o pleito desses Estados tenha encontrado ressonância no STF, a notícia da concessão das liminares teve péssima recepção por parte de alguns analistas que o interpretaram como uma forma de calote ${ }^{58}$. De acordo com informações prestadas em nota técnica pelo Ministério da Fazenda, com a forma de cálculo pleiteada por esses Estados, as dívidas desses com a União seriam reduzidas em mais de $90 \%$ sendo que, na maioria dos casos, os Estados passariam da condição de devedores para credores da União ${ }^{59}$. Em outra nota técnica, o Ministério da Fazenda ressaltou o impacto que a mudança pleiteada por esses Estados teria sobre os demais:

\begin{abstract}
A argumentação técnica equivocada a respeito da metodologia de cálculo do desconto da dívida apresentada por de [sic] Santa Catarina representará um perdão da dívida dos Estados, e não isonomia com o custo da União. A mudança de critério seria, de forma indireta, um desconto que os contribuintes federais dariam aos contribuintes estaduais. Ocorre que esses dois grupos de contribuintes - federais e estaduais - são compostos pelas mesmas pessoas. Diante dessa constatação, é necessário examinar a distribuição dos ganhos e prejuízos e o impacto líquido do perdão que seria concedido aos Estados sobre cada cidadão brasileiro. Caso a União seja obrigada a conceder perdão à dívida de um Estado, o contribuinte daquele ente ganha, mas o mesmo cidadão, como contribuinte da União, vai ter que arcar com uma parcela do perdão dado ao conjunto de todos os Estados beneficiados com a medida. $^{60}$
\end{abstract}

Interessante observar como o Ministério da Fazenda lidou com os problemas do freerider e do overfishing em sua manifestação, questionando a vantagem real que esses Estados esperavam alcançar com a externalização dos custos, considerando que, pelo princípio da isonomia, outros Estados que também adotassem essa estratégia conseguiriam o mesmo benefício. Isto é, dado que o contribuinte estadual é, ao mesmo tempo, contribuinte federal, caso a estratégia de seu Estado fosse bem-sucedida, o benefício alcançado em um primeiro momento pela externalização de seus custos poderia não vir a ser compensado, em um segundo momento, pela eventual externalização dos custos de outros Estados que adotassem igual estratégia.

\footnotetext{
${ }^{57}$ Trecho da decisão proferida pelo Ministro do STF Roberto Barroso nos autos do MS no 34.137/RJ, impetrado pelo Estado do RJ, publicada no DJe n ${ }^{\circ}$ 074/2016, que foi divulgado no dia 18/04/2016 e publicado no dia 19/04/2016, p. 76.

${ }^{58}$ LATIF, Zeina. De quem será a fatura? O Estado de S. Paulo, São Paulo, 18 out. 2018.

${ }^{59}$ BRASIL. Impacto total da liminar concedida pelo STF a Santa Catarina. Nota técnica. Brasília: Ministério da Fazenda, 26 abr. 2016, p. 1.

${ }^{60}$ BRASIL. Redistribuição de custos e benefícios entre contribuintes federais e estaduais. Nota técnica. Brasília: Ministério da Fazenda, 19 abr. 2016, p. 1.
} 
Nesse momento, o STF passou a ocupar o centro da controvérsia sobre as dívidas de Estados com a União. Tanto isso é verdade que, nessa ocasião, governadores de Estados e o próprio Ministro da Fazenda dirigiram-se ao STF para defenderem suas posições e exporem seus argumentos ${ }^{61}$. Por cautela, os Ministros do STF resolveram conceder prazo para a tentativa de conciliação das partes, mantendo nesse período as liminares já concedidas. Informado da celebração de um "acordo federativo", como ficou conhecido, entre os governadores dos Estados e o Ministro da Fazenda, o Plenário do STF, por maioria, resolveu adaptar as liminares concedidas aos termos do referido acordo.

Com a aprovação da $L C n^{o}$ 156/2016, estabelecendo o "Plano de Auxílio aos Estados e ao Distrito Federal", a União foi autorizada a celebrar termos aditivos para conceder: um prazo adicional de 20 anos para pagamento dos contratos de refinanciamento da Lei $\mathrm{n}^{\circ}$ 9.496/1997 (art. $1^{\circ}$ ); uma redução extraordinária de 100\% das parcelas devidas até o final do ano (6 meses de carência) e, no período de janeiro de 2017 a junho de 2018, regressiva de $94,73 \%$ a 5,26\% (art. $3^{\circ}$ ). A lei condiciona a celebração dos termos aditivos à limitação do aumento das despesas primárias correntes (com exceção de transferências constitucionais para Municípios e PASEP), nos dois anos seguintes à celebração desses, à variação da inflação medida pelo IPCA (art. $4^{\circ}$ ). A lei também autoriza a União a receber, em até 2 anos, as parcelas não pagas com base nas liminares concedidas pelo STF nos referidos mandados de segurança $\left(\operatorname{art.} 5^{\circ}\right.$ ). Por fim, a exigência de desistência de eventuais ações judiciais que tenham por objeto a dívida ou contrato a ser refinanciado dessa vez foi prevista na própria lei (art. $1^{\circ}, \S^{\circ}$ ).

Na sequência, Estados acudiram ao STF quer para questionar a constitucionalidade de dispositivos da LC $\mathrm{n}^{\circ}$ 156/2016, quer para requerer a dispensa do cumprimento de exigências nela previstas. Em 2017, o Governador do Estado da Bahia entrou com a ADI $n^{o}$ 5.807, pedindo que o STF desse interpretação conforme à Constituição ao art. $4^{\circ}$, que limita o aumento das despesas primárias correntes à inflação medida pelo IPCA, porque isso violaria, segundo ele, a autonomia dos Estados. O Min. Gilmar Mendes, no entanto, indeferiu o pedido de liminar, ressaltando que:

[...] a adesão às condições estabelecidas no Plano de Auxílio é voluntária e não compulsória. Assim, o ente federado deverá ponderar os possíveis benefícios

\footnotetext{
${ }^{61}$ Conf. cobertura da imprensa: CANES, Michelle. Dívidas de estados levam Ministro da Fazenda ao STF. Agência Brasil, Brasília, 15 abr. 2016; PUPO, Fábio. Governadores defendem no STF juros simples para dívida dos Estados. Valor Econômico, Brasília, 19 abr. 2016; BRASIL. Ministro Fachin reúne governadores e ministro da Fazenda para debater repactuação de dívidas. Notícias STF, Brasília, 19 abr. 2016.
} 
gerados pela renegociação com os encargos correspondentes, optando [...] pela adesão ou não aos termos previstos na Lei Complementar. ${ }^{62}$

Essa ação, no entanto, ainda não foi julgada em caráter definitivo. Ainda em 2017, os Estados de Rondônia e do Rio Grande do Sul ajuizaram, em face da União, a ACO $n^{o} 3.089$ e a PET $n^{\circ} 7.444$, respectivamente, visando à dispensa da condição, estabelecida no referido art. $1^{\circ}, \S 8^{\circ}$, da LC n n $^{\circ}$ 156/2016, de desistência de ações judiciais, para poderem renegociar contratos. A Min ${ }^{a}$ Cármen Lúcia deferiu os respectivos pedidos de liminar, citando precedentes da Corte (as ACOs nº 2.805 e 2.810 e a ADPF nº 382). Já o Amapá não obteve êxito em seu pedido de liminar, formulado na $A C O n^{\circ} 3.091$, para dispensa de "outras condições” estabelecidas pela LC n ${ }^{\circ} 156 / 2016$. Dessa vez, a Ministra considerou que:

Se atendida a pretensão deduzida pelo Estado autor poder-se-ia gerar incorreta percepção de que a celebração de aditivos aos contratos firmados com a União ou seus agentes de fomento dispensaria o cumprimento das exigências legais ou contratuais, tornando a repactuação ato de vontade unilateral do Estado postulante, o qual sequer se submeteria aos prazos legalmente estabelecidos. ${ }^{63}$

\section{COM ALGUNS ESTADOS EM "SITUAÇÃO CALAMITOSA”, STF CONCEDE NOVAS LIMINARES E É ALVO DE CRÍTICAS (2016-2018)}

A reflexão que o presente caso impõe consiste na definição do papel institucional desta Corte, como Tribunal da Federação, diante do iminente colapso fiscal de um ente federativo. [...] Não cabe ao Supremo Tribunal Federal meramente assistir, como um espectador indiferente, o ocaso de um ente federativo e as consequentes violações à dignidade dos cidadãos que, em consequência, serão privados dos seus direitos constitucionais sem que tenham concorrido para esse desfecho.

(Min. Luiz FUX) ${ }^{64}$

O Poder Judiciário não pode assistir impassivo a falência de um Estado da Federação, a prejudicar dezenas de milhões de pessoas que dependem da continuidade da prestação de serviços públicos fundamentais, assegurada a garantia dos direitos básicos, como saúde, educação e segurança [...]

\footnotetext{
${ }^{62}$ Trecho da decisão proferida pelo Ministro do STF Gilmar Mendes nos autos da ADI n ${ }^{\circ}$ 5.807/BA, proposta pelo Governador do Estado da BA, publicada no DJe n ${ }^{\circ}$ 287/2017, que foi divulgado no dia 12/12/2017 e publicado no dia 13/12/2017, p. 102.

${ }^{63}$ Trecho da decisão proferida pela Ministra do STF Cármen Lúcia nos autos da ACO no 3.091/DF, ajuizada pelo Estado do AP em face da União, publicada no DJe n ${ }^{\circ}$ 019/2018, que foi divulgado no dia 01/02/2018 e publicado no dia 02/02/2018, p. 12.

${ }^{64}$ Trecho da decisão proferida pelo Ministro do STF Luiz Fux nos autos da ACO $n^{\circ}$ 2.981/DF, ajuizada pelo Estado do RJ em face da União, do BB e da CEF, publicada no DJe $\mathrm{n}^{\circ} 117 / 2017$, que foi divulgado no dia 02/06/2017 e publicado no dia 05/06/2017, p. 74.
} 
(Min. Marco Aurélio MELLO) ${ }^{65}$

Paralelamente a esse processo de discussão judicial do método de cálculo dos juros das dívidas estaduais, em junho de 2016, o Governador do Rio de Janeiro editou o Decreto $\mathrm{n}^{\circ}$ 45.692, estabelecendo "estado de calamidade pública no âmbito da administração financeira do Estado", em razão da crise econômica pela qual o Estado atravessava, entre outras justificativas. Alguns meses depois, a Assembleia Legislativa aprovou a Lei estadual $n^{\circ}$ 7.483, reconhecendo o referido estado de calamidade pública. Ressalte-se que o próprio governo federal, por meio das MPvs $n^{\circ} 734$ e 736/2016, convertidas nas Leis $n^{\circ} 13.351$ e 13.343/2016, respectivamente, abriu crédito extraordinário para a segurança pública do Estado durante os jogos olímpicos e paraolímpicos. À época, muitos expressaram preocupação com a possibilidade de que essa medida pudesse servir de (mau) precedente para outros Estados que também enfrentavam dificuldades financeiras. Não sem motivo: na sequência, foi a vez de os Governadores do Rio Grande do Sul e de Minas Gerais editarem os Decretos $n^{\circ} 53.303$ e 47.101, respectivamente, de semelhante natureza. Para completar esse quadro, registre-se que, anos após a edição do primeiro decreto de calamidade financeira, mais 4 governadores $^{66}$ editaram recentemente medidas semelhantes, o que sugere que esses Estados adotaram estratégia semelhante à do Rio de Janeiro.

José Maurício CONTI esclarece que o conceito de calamidade pública previsto na legislação está relacionado à ocorrência de desastres naturais - e não ao descontrole ou à falta de planejamento financeiros - e visa a facilitar a prestação de socorro às vítimas ${ }^{67}$. Ele cita alguns instrumentos previstos na legislação para lidar com esse tipo de situação, como créditos extraordinários e fundos orçamentários. De todo modo, como o próprio Estado do Rio de Janeiro viria a reconhecer, ao que consta do relatório da decisão ${ }^{68}$, na ACO no 2981 (que será analisada adiante), a medida visava ensejar a aplicação do art. 65 da LRF, dispensando-o temporariamente do cumprimento do disposto nos arts. $9^{\circ}$ (resultados fiscais e limitação de

\footnotetext{
65 Trecho da decisão proferida pelo Ministro do STF Marco Aurélio nos autos da PET n ${ }^{\circ}$ 7.173/RS (posteriormente apensada aos autos da ACO n ${ }^{\circ}$ 2.755/RS), apresentada pelo Estado do RS em face da União, publicada no DJe $n^{\circ} 171 / 2017$, que foi divulgado no dia 03/08/2017 e publicado no dia 04/08/2017, p. 281.

${ }^{66}$ São eles: RR por meio do Decreto $\mathrm{n}^{\circ}$ 26.404-E, em dezembro de 2018; RN, MT e GO por meio dos Decretos $\mathrm{n}^{\circ}$ 28.689, 07 e 9.392, respectivamente, em janeiro de 2019.

${ }^{67}$ CONTI, José Maurício. Crise leva as finanças públicas ao "estado de calamidade”. Revista Consultor Jurídico, 28 jun. 2016.

${ }^{68}$ Vide síntese do arrazoado do autor feita pelo Ministro do STF Luiz Fux na decisão proferida nos autos da ACO $\mathrm{n}^{\circ}$ 2.981/DF, ajuizada pelo Estado do RJ em face da União, do BB e da CEF, publicada no DJe $\mathrm{n}^{\circ}$ 117/2017, que foi divulgado no dia 02/06/2017 e publicado no dia 05/06/2017, p. 72.
} 
empenho), 23 e 70 (recondução da despesa total com pessoal ao limite), bem como 31 (recondução da dívida consolidada ao limite) do mesmo diploma legal.

Com o agravamento da situação financeira do Rio de Janeiro, que teve como consequência a impontualidade no adimplemento de suas obrigações, diversas ações ${ }^{69}$ foram propostas versando sobre o pagamento tanto das prestações de dívidas do Estado como da remuneração de servidores públicos. A primeira é a $A C O n^{\circ} 2.898$ na qual o Estado pleiteou que aqueles créditos extraordinários abertos pela União em seu favor não fossem objeto de execução de cláusula de contragarantia de contratos inadimplidos. O Min. Ricardo Lewandowski concedeu a liminar, com base no seguinte fundamento:

Na linha da reiterada jurisprudência deste Tribunal, a adoção de medidas coercitivas para impelir a Administração Pública ao cumprimento de seus deveres não pode inviabilizar a prestação, pelo Estado-membro, de serviços públicos essenciais, máxime quando o ente federativo é dependente dos recursos da União. ${ }^{70}$

A segunda é a $A D P F n^{\circ} 405$, que foi proposta pelo Governador do Estado contra diversas medidas de "arresto, sequestro, bloqueio ou penhora" que foram realizadas nas contas do Estado por ordem das Justiças estadual e do trabalho, com vistas a assegurar o pagamento de servidores públicos ou de prestadores de serviço ou, ainda, de definir prioridades de políticas públicas. Por entender que essas violariam competência dos Poderes Executivo e Legislativo, o Plenário do Tribunal, por maioria, concedeu parcialmente a liminar pleiteada.

Imediatamente após haver celebrado um "termo de compromisso" com a União, pelo qual essa se comprometia a aprovar lei instituindo um regime de recuperação fiscal e aquele a adotar, em contrapartida, uma série de medidas de ajuste fiscal - incluindo a não-concessão de reajuste ou aumento de remuneração a servidores públicos -, aprovando as leis que se fizessem necessárias, o Estado do Rio de Janeiro ajuizou a $A C O n^{\circ} 2.981$, em face da União, do $\mathrm{BB}$ e da $\mathrm{CEF}$, com pedido de liminar para que os réus dessem cumprimento imediato a itens constantes do referido acordo, antes mesmo da aprovação das referidas leis ${ }^{71}$. Não obstante,

\footnotetext{
${ }^{69}$ Outras ações importantes merecem ser citadas, como o MS n ${ }^{\circ} 34.483 / R J$, a RCL $n^{\circ} 25.581 / R J$ e a ACO ${ }^{\circ}$ 2.972/DF.

${ }^{70}$ Trecho da decisão proferida pelo Ministro do STF Ricardo Lewandowski nos autos da ACO n ${ }^{\circ} 2.898 / \mathrm{RJ}$, ajuizada pelo Estado do RJ em face da União, publicada no DJe $n^{\circ} 161 / 2016$, que foi divulgado no dia 02/08/2016 e publicado no dia 02/08/2016, p. 12.

${ }^{71}$ Conforme noticiado à época pela imprensa, essa estratégia de se pleitear no Judiciário uma liminar homologando os termos de um acordo, para antecipar os efeitos de uma lei que ainda não havia sido aprovada no Legislativo, decorreria de uma interpretação dos atores envolvidos de que teria sido justamente isso que foi feito nos mandados de segurança que discutiram o método de cálculo dos juros das dívidas, quando as liminares que haviam sido
} 
entre a data de ajuizamento da ação e a da apreciação do pedido de liminar, foram aprovadas, em nível federal, a $L C n^{o}$ 159/2017, instituindo o "Regime de Recuperação Fiscal dos Estados e do Distrito Federal" (chamado de RRF), e, em nível estadual, duas leis com medidas de ajuste previstas no termo de compromisso, pelo que o Min. Luiz Fux concedeu em parte a liminar pleiteada, apenas para suspender a execução de contragarantias de contratos e, assim, evitar possível colapso do Estado antes de que esse pudesse cumprir todas as condições para aderir ao novo regime. $\mathrm{O}$ ministro argumentou que a antecipação integral das condições da lei poderia criar desincentivos para que o Estado prosseguisse com seus esforços de adequação fiscal para aderir ao regime e ressaltou que a Corte não poderia ignorar as consequências de suas decisões ${ }^{72}$. Com a adesão do Estado ao regime, a ação foi julgada extinta. Ressalte-se que, após ter alguns pedidos de liminar negados no passado (inclusive relativas a decisões judiciais ordenando o pagamento da remuneração de servidores públicos), o Estado do Rio Grande do Sul obteve, na PET $n^{\circ} 7.173$, uma liminar com base em fundamento semelhante.

Após ter "derrubado" o veto do Governador, a ALERJ aprovou as Leis n 8.071/2018 e 8.072/2018, concedendo reajustes salariais a servidores públicos de outros Poderes do Estado. Diante disso, o Governador propôs a $A D I n^{\circ} 6.000$, questionando a constitucionalidade das referidas leis por violação a diversas normas constitucionais e alegando risco de exclusão do Estado do RRF, uma vez que o art. $8^{\circ}$, I, da LC n ${ }^{\circ}$ 159/2017 veda a concessão, durante a vigência do referido regime, de reajustes salariais a servidores públicos. O pedido de liminar para suspender a eficácia das referidas leis foi deferido pelo Min. Alexandre de Moraes, ao fundamento de que tais reajustes foram concedidos às vésperas das eleições, o que seria

anteriormente concedidas foram adaptadas aos termos do acordo alcançado pelas partes, ou seja, de que haveria um precedente no STF. Sobre isso, vide: GRANER, Fabio. Saída para crise pode passar por um acordo no Supremo. Valor Econômico, Brasília, 10 jan. 2017; OLIVEIRA, Ribamar. Socorro ao Rio depende de liminar do Supremo. Valor Econômico, Brasília, 25 jan. 2017; e VALOR ECONÔMICO. Acordo da União com o Rio depende de “jabuticaba” legal [Editorial]. Valor Econômico, Brasília, 26 jan. 2017.

72 “Ademais, impõe-se observar os incentivos e os desincentivos que a decisão judicial cria no mundo fenomênico. Antecipar integralmente os termos do Regime de Recuperação Fiscal sem que a parte autora tivesse alcançado todos os requisitos consubstanciaria inegável desincentivo para que continuasse a perseguir os instrumentos de responsabilidade fiscal impostos pela LC n. 159/17. Por outro lado, considerando que qualquer intervenção judicial deve ser excepcional e cirúrgica, conceder o suficiente para que o Estado consiga caminhar a passos próprios incentiva os seus representantes a continuar perseguindo os objetivos de recuperação da saúde fiscal, com a consequente colocação em prática do Plano de Recuperação, a ser trabalhado conjuntamente com a União." Trecho da decisão proferida pelo Ministro do STF Luiz Fux nos autos da ACO n 2.981/DF, ajuizada pelo Estado do RJ em face da União, do BB e da CEF, publicada no DJe $n^{\circ} 117 / 2017$, que foi divulgado no dia 02/06/2017 e publicado no dia 05/06/2017, p. 74. 
vedado pela legislação eleitoral. Como se pôde ver no caso fluminense, apesar de, no termo de compromisso celebrado com a União, o Estado representado por seu Governador ter se obrigado por todos os seus Poderes, alguns desses não parecem ter se sentido comprometidos com um ajuste celebrado pelo Executivo. Esse quadro contrasta com o do Estado vizinho: o Espírito Santo. Nesse, segundo seu então governador, o Executivo teria conseguido angariar o apoio dos demais Poderes, em prol do ajuste fiscal ${ }^{73}$.

\section{CONCLUSÃO}

Pelo que se pôde ver ao longo do presente trabalho, o "reaparecimento" dos fenômenos da indisciplina fiscal e do endividamento estaduais no Brasil parece estar - ao menos, em parte - relacionado a problemas de credibilidade das medidas de ajuste fiscal que foram implementadas ao longo da década de 1990. Assim, ao que tudo indica, aquele mecanismo identificado pelo referencial teórico do início dos anos 2000 para explicar a crise das dívidas estaduais no Brasil ao longo da década de 1990 parece ter voltado a ser explicativo do caso brasileiro. Não obstante, alguns desdobramentos específicos da recente crise fiscal de Estados brasileiros merecem uma maior reflexão da literatura:

Primeiro: diferentemente do que se podia supor à época, a previsão do "no-bailout commitment" em um dispositivo de lei (mesmo que com o status de lei complementar) não se mostrou suficiente para lhe conferir credibilidade. Ainda que o STF tenha quase que imediatamente confirmado a constitucionalidade de tal dispositivo, passados mais de 14 anos de sua aprovação, os Estados não tiveram maiores dificuldades para aprovar - inclusive, mais de uma vez -, no Congresso Nacional, nova(s) lei(s) de mesmo status autorizando a realização de operações que são por esse vedadas, ou seja, estabelecendo exceções de forma tácita. Aliás, sequer foi necessário revogar tal dispositivo - que não só segue em vigor como tem sua redação inalterada, como se jamais houvesse sido afastado - para que essas operações pudessem ser realizadas sem que se cogitasse de ilegalidade. O que o caso brasileiro parece demonstrar é que essa regra formal pode vir a ser afastada se Estados conseguirem derrotar a União em uma nova votação no Congresso Nacional - na realidade, como se viu, se o Poder Legislativo federal, que é composto por representantes oriundos dos Estados, impuser derrotas ao próprio Poder

\footnotetext{
${ }^{73}$ HARTUNG, Paulo. Os Estados por um fio: como sairão do fundo do poço? Fundação FHC, 07 fev. 2019 , p. 2.
} 
Executivo federal. Assim, em outra conjuntura (política, macroeconômica etc.), a União pode não ter condições de sustentar ex post aquele compromisso que havia anunciado ex ante. É preciso ainda reconhecer que, com um histórico de 3 resgates em um período de somente 8 anos, esse desde o início já não desfrutava de muita credibilidade;

Segundo: a leitura dos trechos das decisões do STF (monocráticas e colegiadas) que foram aqui transcritos parece, a princípio, corroborar as críticas feitas por alguns órgãos ligados ao Poder Executivo federal no sentido de que a Corte estaria flexibilizando as medidas de ajuste fiscal que foram implementadas ao longo da década de 1990 e, consequentemente, afetando a credibilidade do pré-compromisso da União de que não socorreria Estados endividados. Todavia, não se deve perder de vista que esse compromisso já havia sido flexibilizado pelo Congresso Nacional, quando da aprovação da LC n ${ }^{\circ}$ 148/2014 que deu margem à rediscussão dos termos daqueles contratos de refinanciamento celebrados com base na Lei $\mathrm{n}^{\circ}$ 9.496/1997, abrindo exceções ao disposto no art. 35 da LRF. Sendo assim, não se pode dizer que decisões recentes da Corte sejam a origem do problema. De todo modo, é preciso observar que há diversas manifestações no sentido de que a execução de medidas para assegurar o cumprimento de obrigações contratuais ou exigências legais pelos Estados não poderia comprometer a prestação de serviços públicos essenciais a sua respectiva população. Alguns Ministros foram, inclusive, bastante claros em suas decisões: a Corte simplesmente não pode permitir a falência de Estados, o que pode transmitir a esses a mensagem de que a União realmente não tem escolha senão socorrê-los;

Terceiro: quanto às liminares, é preciso observar que, quase sempre, os autores justificaram seus pedidos com base no argumento de que seu indeferimento acarretaria danos aos cofres estaduais, o que poderia afetar ou mesmo comprometer a prestação de serviços públicos essenciais a prejudicar a população do Estado. A princípio, poderia parecer que, ao julgar tais pedidos, os Ministros do STF estariam se defrontando somente com o dilema entre conceder uma liminar que beneficia alguns (a população daquele Estado), em detrimento de todos (a população de todo o país). Nem sempre, porém, está claro que - dado o mecanismo identificado pelo referencial teórico -, subjacente a essa decisão entre evitar a interrupção de serviços públicos essenciais naquele Estado e assegurar o cumprimento dos contratos e da legislação fiscal, está o trade-off entre solucionar um problema de curto prazo (o de disponibilidade de caixa daquele Estado) e possivelmente gerar outro de médio e longo prazos (o da indisciplina fiscal dos Estados). Afinal, a mensagem que a concessão dessas liminares acaba 
transmitindo aos Estados é que as medidas de ajuste fiscal podem ser afastadas, casuisticamente, em situações excepcionais de crise grave, que coloquem em risco a continuidade de serviços públicos essenciais - o que, claro, não cria incentivos para que esses se ajustem. É importante observar que, como se viu, alguns Ministros do STF manifestaram consciência do efeito que suas decisões podem ter sobre o comportamento das autoridades estaduais;

Quarto: não se observaram indícios, nos casos analisados, de que os Estados brasileiros tenham efetivamente atuado de forma coordenada em juízo na defesa de interesses comuns em oposição à União. Assim, não parece exato falar em "os Estados" no plural como se esses se comportassem como um único ator. Embora crise e endividamento caracterizem atualmente boa parte dos Estados brasileiros, sua situação fiscal concreta, a magnitude e a composição de suas dívidas variam e muito entre esses. Assim, dada a autonomia dos entes federativos, esses podem não ter incentivos para atuarem conjuntamente. Na realidade, uma estratégia mais atraente em alguns casos pode ser a negociação bilateral, na tentativa de barganhar para si novas concessões da União. E o STF parece ter sido uma peça-chave na estratégia de alguns Estados, no sentido de pleitear um tratamento diferenciado, quase sempre justificada na gravidade e excepcionalidade de sua situação. É certo que algumas ações, como os MS sobre o método de cálculo dos juros da dívida, foram propostas por mais de um Estado. Mas a interpretação que parece mais adequada é que, após a concessão da primeira liminar em favor de Santa Catarina, outros Estados adotaram autonomamente a mesma estratégia amparados pelo princípio da isonomia;

Quinto: ressalte-se, por fim, que embora - ao que tudo indica - tenha havido variação ao longo do tempo no grau de suporte do STF às medidas de ajuste fiscal, para testar essa hipótese seria preciso analisar um espectro mais amplo de decisões tomadas em ações que opõem os interesses de Estados e União em matéria fiscal. O propósito dessa pesquisa, no entanto, foi mais modesto: demonstrar de que modo, no caso brasileiro, aquele mecanismo identificado pelo referencial teórico entrou em operação por meio da atuação do STF. Para isso, bastou examinar uma amostragem suficiente para atender a esse propósito (embora o levantamento tenha abrangido um número maior de casos dos que foram citados). Além disso, optou-se, sempre que possível, pela citação de trechos das decisões, que evidenciam o que foi considerado relevante pelos Ministros para o deferimento ou indeferimento do pedido. É claro que essas manifestações estão atreladas às circunstâncias específicas do caso concreto e não 
necessariamente refletem a orientação da Corte enquanto órgão colegiado (embora, como se viu, algumas dessas decisões tenham sido tomadas pelo próprio Plenário e, em alguns casos, o entendimento adotado por um Ministro seja compartilhado por outro).

\section{REFERÊNCIAS}

Bibliográficas

AFONSO, José Roberto R.; REZENDE, Fernando. $O$ (des)controle do endividamento de Estados e Municípios: análise crítica das normas vigentes e propostas de reforma. Textos para discussão interna, n. 132. Rio de Janeiro: IPEA, jan. 1988. Disponível em: < http://www.ipea.gov.br/portal/images/stories/PDFs/TDs/td_0132.pdf >. Data do acesso: $04 / 11 / 2018$.

ARRETCHE, Marta. Democracia, federalismo e centralização no Brasil. Rio de Janeiro: Editora FGV; Editora Fiocruz, 2012.

BEVILAQUA, Afonso S. State-government bailouts in Brazil. Texto para discussão n 421. Departamento de Economia da PUC-Rio. Versão revisada. Mar. 2000.

BRASIL. Atualização dos contratos de refinanciamento da dívida celebrados entre a União, Estados, o Distrito Federal e Municípios. Nota técnica. Brasília: Ministério da Fazenda, abr. 2016. Disponível em: < http://www.fazenda.gov.br/noticias/2016/abril/fazenda-divulga-notastecnicas-sobre-a-renegociacao-das-dividas-dos-entes-da-federacao/nota-tecnica-3-indexadordas-dividas-v7-2-_final.pdf >. Data do acesso: 10/11/2018.

BRASIL. Boletim de finanças dos entes subnacionais: 2018. Brasília: Ministério da Fazenda. Secretaria do Tesouro Nacional, 13 nov. 2018. Disponível em: < http://www.tesouro.fazenda.gov.br/documents/10180/0/Boletim+de+fina\%C3\%A7as+dos+ente s+subnacionais+vers\%C3\%A3o+final+2/635d1169-777c-46bf-9e98-dab987e9f6f7 >. Data do acesso: $14 / 11 / 2018$.

BRASIL. Em discussão! Revista de Audiências Públicas do Senado Federal, n. 16. Dívida Pública: uma equação difícil. Brasília: Senado Federal, jul. 2013. Disponível em: < https://www.senado.gov.br/NOTICIAS/JORNAL/EMDISCUSSAO/upload/201303\%20-

\%20julho/pdf/em\%20discuss\%C3\%A3o!_julho_2013_internet.pdf $>$. Data do acesso: 21/10/2018.

BRASIL. Exposição da União à insolvência dos entes subnacionais. Texto para discussão. Tesouro Nacional, nov. 2018. Disponível em: < http://www.tesouro.fazenda.gov.br/documents/10180/0/Texto+da+discuss\%C3\%A3o+versao+3+ corrigido/9b49c80d-df45-4e6f-8822-0c511921f4b9 >. Data do acesso: 20/02/2019.

BRASIL. Impacto total da liminar concedida pelo STF a Santa Catarina. Nota técnica. Brasília: Ministério da Fazenda, 26 abr. 2016. Disponível em: < http://fazenda.gov.br/centrais-de- 
conteudos/publicacoes/notas-tecnicas/2016/nota-tecnica-2016-04-26-impacto-total-daliminar-concedida-pelo-stf-a-santa-catarina.pdf > . Data do acesso: 02/02/2019.

BRASIL. Redistribuição de custos e benefícios entre contribuintes federais e estaduais. Nota técnica. Brasília: Ministério da Fazenda, 19 abr. 2016. Disponível em: < http://www.fazenda.gov.br/noticias/2016/abril/fazenda-divulga-notas-tecnicas-sobre-arenegociacao-das-dividas-dos-entes-da-federacao/nota-tecnica-2016-04-19_06-a-relacaoentre-contribuintes-estadual-e-federal.pdf > . Data do acesso: 05/08/2019.

BOUERI, Rogério. PIANCASTELLI, Marcelo. Dívida dos Estados 10 anos depois. Texto para discussão, n. 1366. Rio de Janeiro: IPEA, dez. 2008. Disponível em: < http://www.ipea.gov.br/portal/images/stories/PDFs/TDs/td_1366.pdf >. Data do acesso: 21/10/2018.

BUCHANAN, James M. Federalism as an Ideal Political Order and an Objective for Constitutional Reform. Publius: The Journal of Federalism, v. 25, n. 2, pp. 19-28, inverno 1995.

CARVALHO, Daniel Melo Nunes de; MENDES, Marcos José. O pleito do Estado de Santa Catarina junto ao STF para revisão de sua dívida com a União. Boletim Legislativo, n. 47. Núcleo de Estudos e Pesquisas da Consultoria Legislativa, abr. 2016. Disponível em: < https://www12.senado.leg.br/publicacoes/estudos-legislativos/tipos-de-estudos/boletinslegislativos/bol47 >. Data do acesso: 10/11/2018.

CONTI, José Maurício. Crise leva as finanças públicas ao "estado de calamidade". Revista Consultor Jurídico, 28 jun. 2016. Disponível em: < https://www.conjur.com.br/2016-jun28/contas-vista-crise-leva-financas-publicas-estado-calamidade $>$. Data do acesso: 29/01/2019.

GIAMBIAGI, Fabio. MORA, Mônica. Federalismo e endividamento subnacional: uma discussão sobre a sustentabilidade da dívida estadual e municipal. Texto para discussão, n. 1142. Rio de Janeiro: IPEA, dez. 2005. Disponível em: < http://www.ipea.gov.br/portal/images/stories/PDFs/TDs/td_1142.pdf >. Data do acesso: 01/02/2019.

GIAMBIAGI, Fabio; RIGOLON, Francisco. A renegociação das dívidas e o regime físcal dos Estados. In: GIAMBIAGI, Fabio; MOREIRA, Maurício Mesquita (Orgs.) A economia brasileira nos anos 90. Rio de Janeiro: BNDES, 1999, pp. 111-144. Disponível em: < https://www.bndes.gov.br/SiteBNDES/export/sites/default/bndes_pt/Galerias/Arquivos/conhe cimento/livro/eco90_04.pdf >. Data do acesso: 01/02/2019.

HARTUNG, Paulo. Os Estados por um fio: como sairão do fundo do poço? Debate. São Paulo: Fundação FHC, 07 fev. 2019. Disponível em: < http://fundacaofhc.org.br/imagens/76/33/arq_17633.pdf > . Data do acesso: 16/02/2019.

IMMERGUT, Ellen M. Institutions, Veto Points, and Policy Results: a Comparative Analysis of Health Care. Journal of Public Policy, v. 10, n. 4, pp. 391-416, out.-dez. 1990.

LOUREIRO, Maria Rita. Instituições, política e ajuste fiscal: o Brasil em perspectiva comparada. Revista Brasileira de Ciências Sociais, v. 16, n. 47, pp. 75-96, out. 2011. 
MORA, Mônica. Evolução recente da dívida estadual. Texto para discussão, n. 2185. Rio de Janeiro: IPEA, mar. 2016. Disponível em: < http://www.ipea.gov.br/portal/images/stories/PDFs/TDs/td_2185.pdf $>$. Data do acesso: 01/02/2019.

PELLEGRINI, Josué Alfredo. Dívida estadual. Texto para discussão, n. 110. Brasília: Núcleo de Estudos e Pesquisas do Senado, mar. 2012. Disponível em: < https://www12.senado.leg.br/publicacoes/estudos-legislativos/tipos-de-estudos/textos-paradiscussao/td-110-divida-estadual >. Data do acesso: 01/02/2019.

RODDEN, Jonathan A.; ROSE-ACKERMAN, Susan. Does Federalism Preserve Markets? Virginia Law Review, v. 83, n. 7, pp. 1521-1572, out. 1997.

RODDEN, Jonathan. The Dilemma of Fiscal Federalism: Grants and Fiscal Performance around the World. American Journal of Political Science, v. 46, n. 3, pp. 670-87, jul. 2002.

RODDEN, Jonathan A. Hamilton's Paradox: the promise and peril of fiscal federalism. New York: Cambridge University Press, 2006.

RODDEN, Jonathan; WIBBELS, Erik. Beyond the Fiction of Federalism: Macroeconomic Management in Multitiered Systems. World Politics, v. 54, n. 4, pp. 494-531, jul. 2002.

TIEBOUT, Charles. A Pure Theory of Local Expenditures. The Journal of Political Economy, v. 64 , n. 5 , pp. 416-424, out. 1956.

WEINGAST, Barry R. The Economic Role of Political Institutions: Market-Preserving Federalism and Economic Development. Journal of Law, Economics, \& Organization, v. 11, n. 1, pp. 1-31, abr. 1995.

WIBBELS, Erik. Federalism and the Politics of Macroeconomic Policy and Performance. American Journal of Political Science, v. 44, n. 4, pp. 687-702, out. 2000.

\section{Legislativas}

BRASIL. Constituição da República Federativa do Brasil de 1988. Brasília: Assembleia Nacional Constituinte, 5 out. 1988.

BRASIL. Lei Ordinária nº 7.976. Brasília: Congresso Nacional, 27 dez. 1989.

BRASIL. Lei Ordinária no 8.727. Brasília: Congresso Nacional, 5 nov. 1993.

BRASIL. Medida Provisória nº 1.514. Brasília: Presidência da República, 7 ago. 1996.

BRASIL. Lei Ordinária nº 9.496. Brasília: Congresso Nacional, 11 set. 1997.

BRASIL. Lei Complementar n 101. Brasília: Congresso Nacional, 4 mai. 2000. 
BRASIL. Resolução nº 40. Brasília: Senado Federal, 20 dez. 2001.

BRASIL. Lei Complementar nº 148. Brasília: Congresso Nacional, 25 nov. 2014.

BRASIL. Lei Complementar $n^{o}$ 151. Brasília: Congresso Nacional, 5 ago. 2015.

BRASIL. Decreto nº 8.616. Brasília: Presidência da República, 29 dez. 2015.

BRASIL. Decreto $n^{\circ}$ 8.665. Brasília: Presidência da República, 10 fev. 2016.

BRASIL. Lei Complementar no 156. Brasília: Congresso Nacional, 28 dez. 2016.

BRASIL. Lei Complementar $n^{\circ}$ 159. Brasília: Congresso Nacional, 19 mai. 2017.

GOIÁS. Decreto nº 9.392. Goiânia: Governo do Estado, 21 jan. 2019.

MATO GROSSO. Decreto $n^{\circ}$ 07. Cuiabá: Governo do Estado, 17 jan. 2019.

MINAS GERAIS. Decreto $n^{\circ}$ 47.101. Belo Horizonte: Governo do Estado, 5 dez. 2016.

RIO DE JANEIRO. Decreto $n^{\circ}$ 45.692. Rio de Janeiro: Governo do Estado, 17 jun. 2016.

RIO DE JANEIRO. Lei $n^{\circ}$ 7.483. Rio de Janeiro: Assembleia Legislativa, 08 nov. 2016.

RIO GRANDE DO SUL. Decreto n ${ }^{\circ}$ 53.303. Porto Alegre: Governo do Estado, 21 nov. 2016.

RORAIMA. Decreto $n^{\circ}$ 26.404-E. Boa Vista: Governo do Estado, 28 dez. 2018.

RIO GRANDE DO NORTE. Decreto $n^{o}$ 28.689. Natal: Governo do Estado, 02 jan. 2019.

Jurisprudenciais

BRASIL. Supremo Tribunal Federal (STF). Petição (PET) no 1665/MG, Rel. Min. Moreira Alves. julgada em 15/02/1999, publicada em 24/02/1999.

BRASIL. Supremo Tribunal Federal (STF). Ação Cautelar (AC) nº 6/RJ, Rel ${ }^{a}$ Min $^{a}$ Ellen Gracie, julgada em 06/01/2003, publicada em 04/02/2003.

BRASIL. Supremo Tribunal Federal (STF). Ação Direta de Inconstitucionalidade (ADI) no 2.250/DF, Rel. Min. Ilmar Galvão, julgada em 02/04/2003, publicada em 01/08/2003.

BRASIL. Supremo Tribunal Federal (STF). Ação Cível Originária (ACO) no 2.805/DF, Rel. Min. Edson Fachin, Decisão Min ${ }^{a}$ Cármen Lúcia, julgada em 21/01/2016, publicada em 04/02/2016.

BRASIL. Supremo Tribunal Federal (STF). Ação Cível Originária (ACO) no 2.810/RJ, Rel. Min. Dias Toffoli, Decisão Min ${ }^{a}$ Cármen Lúcia, julgada em 28/01/2016, publicada em 04/02/2016. 
BRASIL. Supremo Tribunal Federal (STF). Arguição de Descumprimento de Preceito Fundamental (ADPF) no 382/DF. Rel. Min. Celso de Mello, Decisão Minª Cármen Lúcia, julgada em 29/01/2016, publicada em 02/02/2016.

BRASIL. Supremo Tribunal Federal (STF). Mandado de Segurança (MS) n ${ }^{\circ}$ 34.023/DF. Rel. Min. Edson Fachin, Rel. p/ acórdão Min. Gilmar Mendes, julgado em 07/04/2016, publicado em 13/10/2017.

BRASIL. Supremo Tribunal Federal (STF). Mandado de Segurança (MS) no 34.137/DF. Rel. Min. Roberto Barroso, julgado em 15/04/2016, publicado em 19/04/2016.

BRASIL. Supremo Tribunal Federal (STF). Ação Direta de Inconstitucionalidade (ADI) n 5.807/BA. Rel. Min. Gilmar Mendes, julgado em 07/12/2017, publicado em 13/12/2017.

BRASIL. Supremo Tribunal Federal (STF). Ação Cível Originária (ACO) n ${ }^{\circ}$ 3.089/DF. Rel. Min. Ricardo Lewandowski, Decisão Minª Cármen Lúcia, julgada em 21/12/2017, publicada em $01 / 02 / 2018$.

BRASIL. Supremo Tribunal Federal (STF). Petição (PET) no 7.444/DF. Rel. Min. Edson Fachin, Decisão Mina Cármen Lúcia, julgada em 26/12/2017, publicada em 02/02/2018.

BRASIL. Supremo Tribunal Federal (STF). Ação Cível Originária (ACO) no 3.091/DF. Rel. Min. Marco Aurélio, Decisão Min ${ }^{a}$ Cármen Lúcia, julgada em 26/12/2017, publicada em 02/02/2018.

BRASIL. Supremo Tribunal Federal (STF). Ação Cível Originária (ACO) no 2.898/RJ. Rel ${ }^{\mathrm{a}}$ Min ${ }^{a}$ Cármen Lúcia, Decisão Min. Ricardo Lewandowski, julgada em 18/07/2016, publicada em 03/08/2016.

BRASIL. Supremo Tribunal Federal (STF). Arguição de Descumprimento de Preceito Fundamental (ADPF) nº 405/RJ. Rel ${ }^{a}$ Min $^{\text {a }}$ Rosa Weber, julgada em 14/06/2017, publicada em 05/02/2018.

BRASIL. Supremo Tribunal Federal (STF). Ação Cível Originária (ACO) nº 2.981/DF. Rel. Min. Luiz Fux, julgada em 31/05/2017, publicada em 05/06/2017.

BRASIL. Supremo Tribunal Federal (STF). Petição (PET) no 7.173/RS. Rel. Min. Marco Aurélio, julgada em 02/08/2017, publicada em 04/08/2017.

BRASIL. Supremo Tribunal Federal (STF). Ação Direta de Inconstitucionalidade (ADI) n ${ }^{\circ}$ 6.000/RJ. Rel. Min. Alexandre de Moraes, julgada em 31/08/2018, publicada em 04/09/2018.

\section{Notícias/colunas na imprensa}

BRASIL. Ministro Fachin reúne governadores e ministro da Fazenda para debater repactuação de dívidas. Notícias STF, Brasília, 19 abr. 2016. Disponível em: < 
http://portal.stf.jus.br/noticias/verNoticiaDetalhe.asp?idConteudo=314826 >. Data do acesso: 26/10/2018.

CANES, Michelle. Dívidas de estados levam ministro da Fazenda ao STF. Agência Brasil, Brasília, 15 abr. 2016. Disponível em: < http://agenciabrasil.ebc.com.br/economia/noticia/201604/dividas-de-estados-levam-ministro-da-fazenda-ao-stf > . Data do acesso: 18/10/2018.

CARNEIRO, Mariana. WIZIACK, Julio. Decisão do STF abre brecha para que estados adiem pagamento à União. Folha de S. Paulo, $1^{\circ}$ out. 2018. Disponível em: < https://www1.folha.uol.com.br/amp/mercado/2018/10/decisao-do-stf-abre-brecha-para-queestados-adiem-pagamento-a-uniao.shtml >. Data do acesso: 16/10/2018.

GRANER, Fabio. Saída para crise pode passar por um acordo no Supremo. Valor Econômico, Brasília, 10 jan. 2017. Disponível em: < https://www.valor.com.br/brasil/ 4831074/saidapara-crise-pode-passar-por-um-acordo-no-supremo $>$. Data do acesso: 21/10/2018.

LATIF, Zeina. De quem será a fatura? O Estado de S. Paulo, São Paulo, 18 out. 2018. Disponível em: < https://economia.estadao.com.br/noticias/geral,de-quem-sera-a-fatura,70002552022 >. Data do acesso: 20/10/2018.

MARTINS, Arícia. Judiciário precisa saber das consequências de decisões, diz Mansueto. Valor Econômico, Brasília, 22 set. 2018. Disponível em: < https://www.valor.com.br/politica/5873591/judiciario-precisa-saber-das-consequencias-dedecisoes-diz-mansueto >. Data do acesso: 28/01/2019.

OLIVEIRA, Ribamar. Socorro ao Rio depende de liminar do Supremo. Valor Econômico, Brasília, 25 jan. 2017. Disponível em: < https://www.valor.com.br/brasil/4846976/socorro-aorio-depende-de-liminar-do-supremo $>$. Data do acesso: 21/10/2018.

OLIVEIRA, Ribamar. LRF não impediu a falência dos Estados. Valor Econômico, Brasília, 24 jan. 2019. Disponível em: < https://www.valor.com.br/brasil/6083399/lrf-nao-impediufalencia-dos-estados >. Data do acesso: 28/01/2019.

PUPO, Fábio. Governadores defendem no STF juros simples para dívida dos Estados. Valor Econômico, Brasília, 19 abr. 2016. Disponível em: < https://www.valor.com.br/brasil/4530311/governadores-defendem-no-stf-juros-simples-paradivida-dos-estados > . Data do acesso: 21/10/2018.

VALOR ECONÔMICO. Pressão dos Estados por recursos ameaça ajuste fiscal [Editorial]. Valor Econômico, Brasília, 19 abr. 2016. Disponível em: < https://www.valor.com.br/opiniao/4778371/pressao-dos-estados-por-recursos-ameaca-ajustefiscal $>$. Data do acesso: 21/10/2018.

VALOR ECONÔMICO. Acordo da União com o Rio depende de "jabuticaba" legal [Editorial]. Valor Econômico, Brasília, 26 jan. 2017. Disponível em: < https://www.valor.com.br/opiniao/4848036/acordo-da-uniao-com-o-rio-depende-dejabuticaba-legal >. Data do acesso: 21/10/2018. 
WATANABE, Marta. Artifícios dificultam punição por descumprimento da LRF. Valor Econômico, Brasília, 28 jan. 2019. Disponível em: < https://www.valor.com.br/brasil/6088223/artificios-dificultam-punicao-por-descumprimentoda-lrf >. Data do acesso: 28/01/2019.

\section{DADOS DA PUBLICAÇÃO}

Categoria: artigo submetido ao double-blind review.

Recebido em: 05/08/2019.

Aceito em: 09/09/2020. 